\title{
EVADING DEBT LIMITATIONS WITH PUBLIC BUILDING AUTHORITIES: THE COSTLY SUBVERSION OF STATE CONSTITUTIONS
}

\author{
G. ROBERT MORRIS, JR.†
}

IN order to sponsor the construction and operation of public works, which are increasingly important in an era of urban and industrial development, government has developed a specialized unit-the public authority. In the recent past, authorities have financed new turnpikes, terminal facilities, marketplaces, water systems, school and government office buildings, and even a planetarium. Commonplace as they are, these institutions nonetheless raise constitutional problems. Specifically, the debt-financing of an authority may involve a violation of restrictions on governmental borrowing. True, compared to a building authority, an operating authority may provoke few such difficulties, for its debt-retired with payments from the commercial users of the facility in question - can be deemed nongovernmental. A building authority, on the other hand, ordinarily finances a construction project by borrowing funds, renting its completed project to a unit of government, and repaying its debt out of the rent. Since the building authority is thus dependent on a government for its income, its debt may be treated as the government's. Building authorities therefore may encounter the limitations on permissible governmental debt found in the various state constitutions.

Adopted by the states in the nineteenth century in response to financial embarrassments, these constitutional restrictions on governmental debt survive today to inhibit the construction of utilities and other public works which are too expensive to be paid for with current revenues. Consequently, evasive devices and fine distinctions are employed to escape debt limitations. Building authorities are the most recent of these devices. However, they involve undue costs which make difficult the achievement of contemporarily desirable publicworks projects.

This article, first, will examine and analyze the legal doctrines utilized to justify building authorities' circumvention of debt limitations and, in conclusion, will attempt an evaluation of the building authority device. By way of introduction to this analysis and evaluation, the article will discuss the origin and nature of public authorities and of debt limitations in state constitutions.

\section{BACKGROUND}

\section{Development and Nature of Public Authorities}

Although two units of local government in Maine assumed authority form at the close of the nineteenth century, the public authority device has developed

$\uparrow$ Associate Professor of Law, Rutgers University School of Law.

1. The Kennebec Water District, incorporated in 1899 , is the first reported public authority which received judicial approval. Kennebec Water Dist. v. City of Waterville, 
principally in the past four decades. The Port of New York Authority, the first public authority of renown and the one which gave these organizations their generic name, was created in $1921 .^{2}$ A few similar organizations were created in the same decade, ${ }^{3}$ but their proliferation awaited the New Deal, under which public works became a matter of national policy and the federal government encouraged the establishment of local authorities in aid of public housing and other projects. ${ }^{4}$ Since World War II, an authority boom has

96 Me. 234, 52 Atl. 774 (1902). An act creating the Waterville New City Hall Commission, the earliest attempted public authority reported, was held unconstitutional in Reynolds $v$. City of Waterville, 92 Me. 292, 42 Atl. 553 (1898).

2. 42 Stat. 174 (1921). The Port of New York Authority in turn was named after the Port of London Authority, which was so nominated because Lloyd George did not want to use the common names, such as "commission," "board," or "agency." Having noticed that each section of the draft enabling act began "Authority is hereby given ...." he suggested the name "Port of London Authority." Cohen, They Bunded Betrer Than TheY KNEw 290 (1946). Other public authorities, such as the Pennsylvania Turnpike Commission, are not so designated. And some organizations called authorities, such as the Tennessee Valley Authority, are not "public authorities" as that phrase is here used since they lack the financial autonomy characteristic of those public-works organizations which depend principally upon the money market for capital.

3. E.g., South Jersey Port Commission (1926), Alabama State Bridge Corporation (1926), Board of Commissioners of the Port of New Orleans (1928), Niagara Frontier Commission (1929). Councti of State Governments, Public Authoritres in the States 23, 25 (1953). Louisville Bridge Commission, Ky. Acts 1928, ch. 74, at 263.

4. Federal public works of primarily local benefit encountered constitutional difficulties when the federal government was forbidden to condemn land for local housing projects. United States v. Certain Lands in City of Louisville, 9 F. Supp. 137 (W.D. Ky.), aff'd, $7 S$ F.2d 684 (6th Cir.), dismissed on motion of the government, 294 U.S. 735 (1935).

Federal grants in aid to state and local governments for public works traditionally had supplied only part of the cost of construction; the grantee government financed the remainder. When the depression prevented state and local governments from matching federal grants, the federal government lent the remainder, to preserve the tradition of matched grants. Williams, Grants-In-Aid Under Public Works Administration 42, 48-49 (1939). However, the federal government feared legal hurdles to such a plan. In December 1934, President Roosevelt wrote the governor of each state that:

In the event that an additional public works program is authorized at the coming scssion of Congress, I should like to see the municipalities of your state legally able to take full advantage of such a program. With this in mind, I have instructed Administrator Ickes to place at your disposal the Legal Division of the Public Works Administration for the purpose of suggesting bills which if enacted into law would enable municipalities of your State to secure the benefits of this phase of the recovery program.

Our experience in the past eighteen months has brought to light the difficulty of gearing the legal machinery which has served municipalities of your State adequately for decades to the speed with which the Federal Government must extend credit to achieve desired results. It has been found that revision of the procedure relative to municipal financing is essential, at least for the duration of the present emergency. . . .

(Emphasis added.) The letter suggested either the extension of municipal powers to the construction and finance of self-liquidating public-service enterprises or the creation of new public corporations with such powers. Foley, Revenue Financing of Public Enter- 
spawned still more of these institutions at the state and local level. Despite the occasional rises in interest rates which have dampened this boom, the public authority is currently considered a normal institutional form for public-works development. ${ }^{5}$ In periods of prosperity, rapid urbanization, numerous automobiles, and high birth rates, new authorities build utility systems, roads and schools. And in leaner years, when public works become instruments of economic recovery, the federal government offers to lend local authorities funds to stimulate employment-creating public construction.

Usually, the public authority has the following important characteristics and methods of operation. It finances public works by borrowing, levies charges calculated primarily to repay its debt, and, when the debt is retired, customarily conveys the completed project to a traditional unit of government. In form, practically all authorities at all levels of government are organized as public corporations, ${ }^{6}$ with multistate authorities being created by interstate

prises, 35 MrCH. L. REv. 1, 5-6 (1936). Mr. Foley was the director of the legal division of the PWA and actively advocated the creation of authorities, not only by advising state governments pursuant to presidential command, but also by urging the legality and desirability of authorities through articles in legal periodicals. See ibid; Foley, Some Recent Developments in the Law Relating to Municipal Financing of Public Works, 4 Fordeam L. Rev. 13 (1935); Foley, The Case of Tierney v. Cohen, 5 Fordeas I. REv. 73 (1936) ; Foley, Legal Aspects of Low-Rent Housing in New York, 6 FoRdHAx L. Rev. 1 (1937); Foley, Loze-Rent Housing and State Financing, 85 U. PA. L. REv. 239 (1937).

5. For example, President Eisenhower recently advocated federal legisiation to encourage local school building authorities to help solve the current schoolroom shortage. The President stated:

Many school districts cannot borrow to build schools because of restrictive debt limits. They need some other form of financing. Therefore, [this] proposal is designed to facilitate immediate construction of schools without local borrowing by the school district.

To expand school construction, several States have already created special statewide school building agencies. These can borrow advantageously, since they represent the combined credit of many communities. After building schools, the agency rents them to school districts. The local community under its lease gets a new school without borrowing.

I now propose the wider adoption of this tested method of accelerating school construction. Under this proposal the Federal Government would share with the States in establishing and maintaining for State school-building agencies an initial reserve fund equal to 1 year's payment on principal and interest.

The State school-building agency, working in cooperation with the State educational officials, would issue its bonds through the customary investment channels, then build schools for lease to local school districts. Rentals would be sufficient to cover the payments on principal and interest of the bonds outstanding. ... In time, the payments ... would permit repayment of the initial Federal and State advances. When all its financial obligations to the agency are met, the local school district takes title to its building.

Message from the President of the United States, H.R. Doc. No. 84, 84th Cong., 1st Sess. 3 (1955).

6. Customarily, enabling acts describe authorities as "bodies public and corporate." Some authorities, however, are not so designated and appear, from their enabling acts, 
compact ${ }^{7}$ or an act of Congress, ${ }^{8}$ and those on the state level by special acts of the legislature. In many jurisdictions, enabling legislation patterned after general incorporation acts empowers county and municipal governments to

to be nothing but government bureaus. E.g., California Toll Bridge Authority, Pennsylvania Turnpike Commission, State Bridge Commission of Ohio, Washington Toll Bridge Commission, and West Virginia Turnpike Commission. However, the corporate norm is so well established that the courts readily treat even these as corporations. Thus federal courts have assumed diversity jurisdiction over suits against the Pennsylvania Turnpike Commission despite objection that the eleventh amendment, depriving federal courts of jurisdiction in suits against the states, prevented this action. "The fact that the commission is not a corporation does not make it any less a distinct legal entity. It is an unincorporated association, sometimes called a quasi corporation, with power to sue and be sued in its own name, and as such it assumes the citizenship of its members." HunkinConkey Const. Co. v. Pennsylvania Turnpike Comm'n, 34 F. Supp. 26, 28-29 (Mi.D. Pa. 1940). This case was followed in Iowes v. Pennsylvania Turnpike Comm'n, $125 \mathrm{~F}$. Supp. 681 (M.D. Pa. 1954) ; Darby v. L. G. DeFelice \& Son, 94 F. Supp. 535 (E.D. Pa. 1950). Similarly, the West Virginia Turnpike Commission has been subjected to federal diversity jurisdiction. Guaranty Trust Co. v. West Virginia Turnpike Comm'n, 109 F. Supp. 286 (S.D.W. Va. 1952).

Though the California Toll Bridge Authority has been held immune from federal jurisdiction under the eleventh amendment because it is not a jural entity separate from the state, Fowler v. California Toll Bridge Authority, 46 F. Supp. 299 (N.D. Calif. 1941), it has been treated as a public corporation for other purposes, California Toll Bridge Authority v. Kelly, 218 Cal. 7, 21 P.2d 425 (1933).

On the other hand, some courts have refused to recognize as corporations authorities designated as corporations by their enabling acts. For example, the Indiana Toll Road Commission Act was held not violative of the constitutional prohibition against special carporate charters because the Commission was created for a public purpose and "despite the fact that the commission is given the characteristics of a corporation, it is still a commission of the State of Indiana." Ennis v. State Highway Comm'n, 231 Ind. 311, 324-25, 108 N.E.2d 687, 694 (1952).

Nor does an authority's corporate entity so separate it that it has none of the attributes of government. Thus it may be sufficiently identified with the state to enjoy sovereign immunity. For example, the South Carolina Public Service Authority is immune from tort liability because it is "completely identified with the state in the performance of its public functions [hydro-electric power], which are unquestionably of a governmental character." Rice Hope Plantation v. South Carolina Public Serv. Authority, 216 S.C. 500, 517, 59 S.E.2d 132, 138-39 (1950). Even the courts of Pennsylvania, which created a corporate separateness, Pennsylvania Turnpike Comm'n v. Baldwin Bros., $44 \mathrm{~Pa}$. D. \& C. 462 (C.P. 1942) (statute requiring notice within ninety days on all claims against construction bonds given the Commonwealth held not to apply to bonds given the Commission because it is a corporation separate from the Commonwealth), where the legislature had not, granted the Commission sovereign immunity from actions in tort, House v. Pennsylvania Turnpike Comm'n, 45 Pa. D. \& C. 677 (C.P. 1942).

7. E.g., Port of New York Authority, 42 Stat. 174 (1921); Lake Champlain Bridge Commission, 45 Stat. 120 (1928), 49 Stat. 736 (1935), 49 Stat. 1472 (1936); Delaware River Port Authority, 47 Stat. 308 (1932), 66 Stat. 738 (1952); Maine-New Hampshire Interstate Bridge Authority, 50 Stat. 538 (1937); Tennessee-Missouri Bridge Commission, 63 Stat. 930 (1949) ; Bi-State [Missouri-Illinois] Development Authority, 64 Stat. 568 (1950).

8. Congress has established a number of authorities to operate international and interstate bridges. Omaha-Council Bluffs Missouri River Bridge Board of Trustees, 
create authorities by filing certificates in the nature of articles of incorporation. ${ }^{8}$ In keeping with the corporate form, all authorities are governed by a board of directors, never by one man. Some boards are elected, ${ }^{10}$ but usually the directors

46 Stat. 544 (1930); Great Lakes Bridge Commission, 46 Stat. 809 (1930); St. Lawrence Bridge Commission, 48 Stat. 141 (1933) ; Cairo Bridge Commission, 48 Stat. 577 (1934); Oregon-Washington Bridge Board of Trustees, 48 Stat. 949 (1934); Port Arthur Bridge Commission, 48 Stat. 1008 (1934); Sisterville Bridge Board of Trustees, 48 Stat. 1013 (1934); Niagara Falls Bridge Commission, 52 Stat. 767 (1938); Arkansas-Mississippi Bridge Commission, 53 Stat. 747 (1939); Dubuque Bridge Commission, 53 Stat. 1051 (1939); Vicksburg Bridge Commission, 53 Stat. 1267 (1939); White County Bridge Commission, 55 Stat. 140 (1941); Clinton Bridge Commission, 58 Stat. 846 (1944): Sabine Lake Bridge \& Causeway Authority, 65 Stat. 695 (1951); Muscatine Bridge Commission, 70 Stat. 669 (1956).

The success of these authorities has varied. The Cairo Bridge Commission, created to bridge the Mississippi and Ohio Rivers, completed its task, but the Oregon-Washington Bridge Board of Trustees, established to bridge the Columbia near its mouth, never began its project. Some authorities were instituted to take charge of existing facilities: the Vicksburg Bridge Commission to manage a bankrupt private corporation's toll bridge, and the Muscatine Bridge Commission to rebuild a bridge damaged by floods.

9. See, e.g., The Pennsylvania Municipality Authorities Act of 1945, PA. Star. Ann. tit. 53, $\$$ 301-74 (1957). In Wisconsin, all public authorities are incorporated under the general nonprofit incorporation statute. See State ex rel. Thomson v. Giessel, 265 Wis. 185, 60 N.W.2d 873 (1953) ; State ex rel. Thomson v. Giessel, 267 Wis. 331, 65 N.W.2d 529 (1954); Wis. Stat. $\$ \$ 15.96,40.22,40.305,182.32-48$ (1955). This procedure is apparently followed to avoid the constitutional prohibition against special charters of incorporation. Indiana school building authorities are similarly incorporated under the general incorporation act, IND. STAT. ANN. $\$ \$ 28-3220,-3221,-3223$ (1948), $\$ \$ 2 \$-3222$, -3224 to -3233 (Supp. 1955), as is the Kentucky Armory Board, Councli of State GorERNAENTS, op. cit. supra note 3 , at 38 .

Some housing authority legislation deviates slightly from this corporate pattern. The Louisiana Housing Authority Act, for instance, purports to create a housing authority in each city and parish, but the organization remains dormant until the governing board of the city or parish declares by resolution that one is needed. LA. Rev. Stat. ANn. $\$ 40: 391$ (1950). South Carolina permitted the formation of county housing authorities by action of the county's legislative delegation rather than its governing board. See Benjamin $v$. Housing Authority, 198 S.C. 79, 15 S.E.2d 737 (1941). Some enabling acts require that municipalities obtain permission from state officials before incorporating an authority. E.g., Illinois Housing Authority Act., Ir.. Rev. STaT. ch. 67\%/2, \$ 3 (1957).

New York City's attempt to create a power authority without special legislative permission was invalidated in Tierney v. Cohen, 268 N.Y. 464, 198 N.E. 225 (1935). And an act permitting private individuals to incorporate and manage a turnpike authority was held unconstitutional insofar as it granted the authority tax-exempt status. CarolinaVirginia Coastal Highway v. Coastal Turnpike Authority, 237 N.C. 52, 74 S.E.2d 310 (1953).

10. The directors of power authorities in Nebraska are chosen by the electorate of the area in which the authorities provide electricity. NEB. Rev. Stat. Ann. $\$ \$ 70-601$ (2), $-609.01,-614.01$ (1950). The Jamestown (R.I.) Bridge Commission is governed by a committee elected at the town meeting. Powers $e x$ rel. Foley v. Caswell, 79 R.I. 188, 86 A.2d 379 (1952). Housing Authorities in the towns (but not the cities) of Massachusetts consist of one state-appointed and four locally elected members. Mass. ANN. LAws ch. 121, $\$ 26$ L (1957). The ex officio device also can result in an elected board of directors. For ex- 
are appointed by the unit of government sponsoring the authority ${ }^{11}$ or, as officers of that government, are directors ex officio. ${ }^{12}$

The activities of public authorities are susceptible of various classifications, but, for the purposes of this article, the distinction between operating and building authorities is of principal importance. An operating authority is, in a sense, a publicly owned business in that it invariably directs enterprises, such as a turnpike, sewerage system or airport, which earn commercial revenues from private users. Accordingly, operating authorities are undertaken only after study has indicated that business income will be adequate to meet their current expenses and retire their debt. Building authorities, on the other hand, have neither private customers nor commercial income. Instead, they construct projects useful to some government, and then derive their income exclusively from governmental rents. Typically, they construct schools and office buildings to house state or municipal agencies, although some build roads or

ample, the Dade County (Fla.) Port Authority is composed of the Board of County Commissioners who, pursuant to statute, adopted the port authority title and entered the turnpike and airport business. See Florida State Turnpike Authority v. MacVicar, 67 So. 2 d 210 (Fla. 1953).

11. Generally, the executive or governing board of the sponsoring unit of government appoints the authority's board. Appointments to authority directorship on the state level often require the concurrence of the senate.

Some boards are appointed by other officials, however. Members of the Housing Authority of Darlington County, S.C., were selected by the state senator from that county. Benjamin v. Housing Authority, 198 S.C. 79, 15 S.E.2d 737 (1941). In Pennsylvania, the Speaker of the House and the President of the Senate each appoint one member to the General State Authority and to the State Highway and Bridge Authority. PA. Stat. ANN. tit. 71, § 1707.2, tit. 36, § 3603 (Supp. 1957). The board of the Lower Neches Valley (Texas) Authority is appointed by the State Board of Water Engineers, CouncIl of STATE GovernMrents, op. cit. supra note 3 , at 45.

Generally, where an authority serves more than one community, some members of the board are appointed by the government of each area. The Chicago Regional Port District employs a novel device. Three members are appointed by the Mayor of Chicago and four by the Governor of Illinois, but the Mayor's appointees must be approved by the Governor and the Governor's appointees by the Mayor. In.. Rev. Stat. ch. 19, § 164 (Supp. 1957).

12. Since public authorities projects often are related closely to other government activities, it is not unusual for the superior executive officer of a related government department to be a member of an authority's board ex officio The senior state highway official, for instance, is often a member of a turnpike authority. Ex officio directors are more common in building authorities than in operating authorities. CounciL of STATE GoverNMENTs, op. cit. supra note 3 , at 41,42 . Although most ex officio directors are drawn from the executive branch of government, the Chief Justice of the Supreme Court of Georgia is a member of the Georgia State Office Building Authority, GA. Cone Ans. $\$ 91-502 a$ (Supp. 1955), and the Kansas Turnpike Authority includes the chairmen of the house and senate highway committees. KAN. GeN. Stat. ANn. \$68-2003 (Supp. 1957). In Pennsylvania, the General State Authority and the State Highway and Bridge Authority have, as directors, the Speaker of the House, the President pro tempore of the Senate and the minority leaders of both houses. PA. Stat. Ans. tit. $71, \S 1707.2$, tit. 36 , $\S 3603$ (Supp. 1957). 
bridges which they rent to the local government for operation either as freeways or toll facilities. ${ }^{13}$

Building authorities may, on occasion, have potential private income, ${ }^{\mathbf{1 4}}$ but, generally, they have not built projects in order to exploit a commercial market and, in all but a few cases, their potential commercial earnings could never cover operating costs and debt service. Thus, while operating authorities must attract private capital by convincing the financial community that commercial income will cover expenses, interest and amortization, building authorities can attract investors on the basis of prospective government rentals alone, irrespective of possible commercial income should the government abandon the projects.

\section{Constitutional Debt Restrictions and Their Exceptions}

Since operating authorities appear financially separate from the governments which sponsor them, their debts have generally been upheld in the face of constitutional debt limits. Building authorities, on the other hand, are clearly integrated into their lessee-governments' fiscal patterns, and they have been held unconstitutional or upheld only upon tortured reasoning.

The constitutions of all but eight states ${ }^{15}$ limit the exercise of legislative discretion with respect to state debt. In twenty jurisdictions, the problem is left to the electorate's judgment by requiring a referendum before a significant state debt may be incurred. ${ }^{16}$ In the remaining twenty, ${ }^{17}$ debt of any

13. The Georgia State Bridge Building Authority rents highways to the state for toll-free operation. See GA. Cone ANN. \$ 95-2308 (Supp. 1955). The State Highway and Bridge Authority of Pennsylvania also rents its projects to the state, and because of their toll-free operation, its projects are eligible for and have received federal highway aid funds. Council of State Governarents, op. cit. supra note 3, app. A, at 17. Among the Florida State Improvement Commission's many projects, including buildings, bridges and highways, some road projects are operated toll-free, while the Lower Tampa Bay Bridge is operated by the state as a toll facility. Id. app. A, at 12-13; see State v. Florida State Improvement Comm'n, 52 So. 2d 277 (Fla. 1951).

14. Should they cease renting to units of government, they could perhaps rent their office buildings to private tenants. Their school buildings might have commercial value and they could charge tolls on their highways and bridges.

15. Connecticut, Delaware, Maryland, Massachusetts, Mississippi, New Hampshire, Tennessee and Vermont. In two, however, approval by more than a simple majority of the legislature is necessary: Delaware requires three-fourths; Massachusetts, two-thirds. The various state debt limits are more fully detailed in Council of STATE Governarents, op. cit. supra note 3 , at $15-17$.

16. Arkansas, California, Idaho, Illinois, Iowa, Kansas, Kentucky, Maine, Missouri, Montana, New Jersey, New Mexico, New York, North Carolina, Oklahoma, Rhode Island, South Carolina, Virginia, Washington and Wyoming. Six of these also permit the legislature to exercise limited discretion so long as the state's debt does not exceed a specified amount: California $(\$ 300,000)$, Idaho $(\$ 2,000,000)$, Kansas $(\$ 1,000,000)$, Maine $(\$ 2,000$,$000)$, Montana $(\$ 100,000)$, and Rhode Island $(\$ 50,000)$. Three others provide a variable ceiling: New Jersey (1\% of annual appropriations), North Carolina (two thirds of amount debt has been reduced in previous biennium), and Wyoming (amount of tax revenue for the current year).

17. Alabama, Arizona, Colorado, Florida, Georgia, Indiana, Louisiana, Michigan, 
consequence (unless for extraordinary purposes such as defense against insurrection or invasion) must be authorized by a constitutional amendment. Additionally, in nearly every jurisdiction the state constitution limits the debts of counties and municipalities to a percentage of the value of taxable property within their bounds. ${ }^{18}$

All of these restrictions have their origins in the financial debacles of the previous century. Following the panic of 1837, the states which had been embarrassed by heavy indebtedness adopted constitutional debt limits. Subsequently, new states, upon entering the union, imitated their predecessors. ${ }^{19}$ Because the resultant widespread debt limits later precluded state participation in the railroad boom of the mid-nineteenth century, railway expansion was largely financed by municipalities. A given municipality would either guarantee railroad obligations in order to increase their marketability, or purchase railroad stock with the proceeds from a sale of municipal bonds. Consequently, when the panic of 1873 found the municipalities overextended, the states responded with municipal debt limits, which soon became commonplace constitutional provisions. ${ }^{20}$

Nonetheless, many towns, especially those in prairie states, continued to regard borrowed capital as indispensable for financing public utilities, schools and roads. Devices were therefore conceived in order to avoid the recent constitutional amendments. Three of these devices, developed long before the evolution of public authorities and permitting evasion in non-authority contexts, are important in the law of building authorities.

Minnesota, Nebraska, Nevada, North Dakota, Ohio, Oregon, Pennsylvania, South Dakota, Texas, Utah, West Virginia, and Wisconsin.

18. The percentages differ, however. Most debt limits do not exceed $10 \%$. None surpass the $18 \%$ permitted in Virginia. See VA. Const. art. VIII, $\$ 127$. Some states provide different limils for various municipalities, see, e.g., PA. Const. art. IX, $\$ 8$ (7\% generally, but $13 \% / 2 \%$ for Philadelphia), and some permit additional indebtedness for local utilities, see, e.g., Ara. Const. art. XII, \$ 225 (additional 3\%); Wash. Const. art. VIII, $\S 6(5 \%)$. The Oklahoma constitution recently was amended to authorize additional indebtedness for school buildings. Orta. Consr. art. $\mathrm{X}, \S 26$. Some states provide two limits. Municipal governments may not exceed the lower one unless empowered by a referendum. See, e.g., PA. Const. art. IX, $\S 8$ (voter approval required for all debts above $2 \%$ generally, $3 \%$ for Philadelphia) ; WAsH. Const. art. VIII, $\$ 6$ (threefifths voter approval required for all debts over $1 \frac{1}{2} \%$ ).

Although Idaho generally limits municipal debts to an amount equivalent to current municipal income, the electorate, by a two-thirds vote, may authorize indebtedness of any amount. IрAно Const. art. VIII, \$3. See also Kx. Consr. \$157. Oklahoma coordinates the current income and the percentage of assessed property limits and allows the government to incur indebtedness not in excess of current annual revenues, yet permits additional indebtedness, up to a total of $5 \%$ of the assessed valuation, upon referendum. OrLa. Const. art X, § 26.

Some state constitutions impose no municipal debt limit; instead statutes assume this function. Stason, State Administrative Supervision of Municipal Indebtedness, 30 Mrck. L. REv. \&33, 838 n.7 (1932).

19. Council of State Governments, op. cit. supra note 3 , at 11-12.

20. Williams \& Nehemkis, Municipal Improvements as Affected by Constitutional Debt Linitations, 37 Colum. L. Rev. 177-79 (1937). 
Executory Contracts. On the theory that debt limits require the government to exist on a pay-as-you-go but not a cash-on-the-barrel-head basis, government obligations upon executory contracts for current expenses have been held not to be debts within the meaning of the state constitutions. For example, salary commitments to government employees for the current year are deemed not to be debts, so long as the government's budget-including the salary accounts -is balanced, even though the government is contractually bound. If, however, the salaries cannot be paid from estimated revenues, the executory salary obligations create a debt. Thus, to be exempt from debt restriction, the obligation must involve a current expense (salaries, supplies, services or rents), be charged to a valid appropriation, and must not exceed estimated current revenue. Some jurisdictions permit an important extension of this rule to include multiyear executory contracts, so that a contract for hire for five years will not create a debt if the salary is within estimated revenues. Capital acquisitions, however, are not "current expenses" and therefore not within the executory contract exception. ${ }^{21}$

Special Districts. When a municipality has exhausted its permissible debt, new projects can be financed by adding a new government unit, such as a special park, water, or drainage district. Even if the district and the municipality are co-extensive, the special district constitutes a separate corporation whose debt is unrelated to that of the municipality. ${ }^{22}$ In any event, debt limits are often construed as inapplicable to special districts, although districts have many characteristics, including the power to tax, in common with municipalities. Even if the debt limit is construed to restrict a special district, the debt potential of an area doubles when a district is superimposed upon a municipality.

Special Funds. Finally, obligations payable from a "special fund" are not considered debts within the meaning of the constitutional limits. ${ }^{23}$ This exception was originally employed to permit the financing of local improvements, such as paved streets, through assessments which were levied upon the benefitted, abutting land and which, conceptually at least, were paid into a special fund. The courts later extended the exception to encompass revenue bonds financing public utilities and payable from utility receipts. The judicial theory was that the government which issues these bonds acts solely as an agent for collecting money to be applied against them, and that the owners of assessed property and the utility rate-payers are the actual debtors. ${ }^{24}$ In distinct con-

21. Hoyt \& Fordham, Constitutional Restrictions Upon Public Debt in North Carolina, 16 N.C.L. Rev. 329, 343-45 (1938).

22. Williams \& Nehemkis, supra note 20, at 201-06; Hoyt \& Fordham, supra note 21, at 356; Bollens, Spectal District Governments In The United States, pp. $7-9$ (1957).

23. Williams \& Nehemkis, supra note 20 , at 187-88; 15 McQuillin, MUnicipal CoRPORATIONS $\$ 41.32$ (3d ed. 1950).

24. "[T]here is no liability against the city. The special fund provided for and the [benefited] property are the sources from which the holders of the bonds and certificates must receive their pay, the city authorities acting merely as an agency for making and collecting the assessments, and as the custodian of the fund when the assessments are 
trast with the special-district device-which reduplicates the corporate structure of local government-the special-fund theory pierces the corporate veil and construes the debt as an obligation of the ultimate payers.

Two important qualifications of the special-fund theory reduce its utility for public authorities. If the government obligates itself to "feed" the fund-to supplement it with tax receipts-constitutional debt limits apply, ${ }^{25}$ since the government has gone beyond its role as a collection agent and has undertaken partial payment of the debt. In addition, some jurisdictions have adopted the "restricted" special-fund theory, which prohibits any mortgage securing revenue bonds if it encumbers property formerly owned by the government free and clear. Only purchase-money mortgages are permitted, the rationale being that, if the mortgage encumbers pre-existing property, the threat of foreclosure and consequent loss of that property may coerce the government into redeeming the property by paying the debt from general government funds. ${ }^{26}$

\section{Public Authorities and Debt Limits Before the Courts}

Both the special-district and special-fund theories have relieved operating authorities from constitutional debt limits. The first public authority, the Kennebec Water District, was upheld on a special-district theory. ${ }^{27}$ Incorporated in 1899 to supersede privately owned water systems in and around Waterville, Maine, to pay the costs of acquisition with borrowed money, and to service its debt with revenue from the systems, Kennebec was a typical special district (except that it lacked the power to tax). Although the city of Waterville had nearly exhausted its constitutional borrowing power, the Supreme Judicial Court of Maine held the district's debt legitimate by finding the constitutional

collected. In this they do not act as the agents of the city, but as special agents, to accomplish a public end." Quill v. City of Indianapolis, 124 Ind. 292, 298, 23 N.E. 788, 790 (1890).

25. Williams \& Nehemkis, supra note 20 , at $198-200$.

26. This rule was first adopted in City of Joliet v. Alexander, 194 Ill. 457, 62 N.E. 861 (1902). Since investors in government obligations often do not demand a mortgage, the restriction as to security does not prove overly burdensome. The rule included a more binding restriction which prohibited the pledge of prior income to the payment of revenue bonds. If the facility to be improved had been operating at a profit, and that profit had previously been paid into the government's general fund, any pledge of that income would be unconstitutional because the taxpayers would have to pay increased taxes to replace the revenue which the pledge diverted from the general fund to the payment of the bonds. This restriction effectively prohibited revenue bond financing of utility improvements unless revenues derived from the improvements could be segregated. Illinois, therefore, rejected this branch of the restricted special-fund theory in Ward v. City of Chicago, 342 III. 167, 173 N.E. 810 (1930). Missouri, which adopted the restricted theory in Bell v. City of Fayette, 325 Mo. 75, 28 S.W.2d 356 (1930), rejected it in Grossman v. Public Water Supply Dist. No. 1, 339 Mo. 344, 96 S.W.2d 701 (1936). However, the restricted special-fund theory still has vitality in a few states. Hesse v. City of Watertown, 57 S.D. 325, 232 N.W. 53 (1930) ; Fjeldsted v. Ogden City, 83 Utah 278, 28 P.2d 144 (1933). And Wisconsin has adopted the restriction against mortgages. State ex rel. Morgan v. City of Portage, 174 Wis. 588, 184 N.W. 376 (1921). See Williams \& Nehemkis, supra note 20 , at 192-97, 209-11.

27. Kennebec Water Dist. v. City of Waterville, 96 Me. 234, 52 Atl. 774 (1902). 
limitation inapplicable to special districts, and by refusing to impute the district's debts to the city. The court took the view that, as a separate corporate entity, the district could incur obligations which were not city debts. Though the opinion rested on the special-district theory, the special-fund theory would have been equally appropriate, because water revenues are clearly special funds. Not only do the terms of a typical special-fund obligation make the issuer liable only for amounts in or owed the fund itself, but also the Kennebec Water District's bonds-even if they were in form unconditional promises to paywould be special-fund obligations, for the district had only special-fund income.

The cases illustrate, however, that the special-district and special-fund exceptions to the debt limit cannot be utilized by a building authority save in exceptional situations. In Reynolds v. City of Waterville, ${ }^{28}$ for example, the same court which, four years later, was to uphold the first operating authority in the Kennebec case, invalidated a building authority. Reasoning with a perception unusual in an initial review of a novel device, the court held that the Waterville New City Hall Building Commission, though a separate corporate body, was merely a trustee under a deed of trust in the nature of a mortgage, and that its bonds therefore constituted debts of the city in excess of the legal limit.

Actually, the documents in question-typical of those ustually found in building authority cases - did not purport to create a mortgage. After a special act of the legislature had incorporated a commission to build a city hall, the city conveyed a lot to the commission, which then hired a building contractor to erect the hall on this land. The commission planned to issue its bonds to pay the contractor, and the city expected to rent the hall from the commission at a rate sufficient to pay interest and retire the bonds. Nevertheless, the Reynolds court, having reviewed these facts" and endorsed the rule which exempts multi-year executory contracts from a debt limitation, ${ }^{29}$ went on to find that the City of Waterville was not merely contracting to hire the hall's use.

It would not be a misinterpretation to say that the city of Waterville, instead of leasing the property, undertakes to purchase or pay for it on the installment plan, and that what are called rentals for the hall are merely partial payments on its cost. ... [T] he true nature of the transaction is rather the hiring of money by the city upon the security of city property through the intervention of a trustee, the title to the property being and remaining in the city from the beginning to the end, stubject only to the lien upon it in favor of bondholders for money to be lent. ${ }^{30}$

Such an arrangement, said the court, is but a form of mortgage and hence the bonds were debts of the city-moitgagor violating the debt limitation in the Maine constitution. ${ }^{31}$

28. 92 Me. 292, 42 Atl. 553 (1898).

29. The court stated: "[O]n this principal, a town or a city may contract for the use of a hall for a term of years ...." Id. at 303, 42 Atl. at 555 .

30. Id. at 304, 42 Atl. at 555 .

31. Language of trust in the city's deed of the lot to the commission aided the court in this interpretation. The commission was granted the land in trust for building authority 
The court's reasoning is not without its logical appeal, since building authorities and mortgage trustees have many common characteristics. Both are jural personalities separate from the lenders and the ultimate enjoyer of the res, and both have duties which spring from documents purporting to give them title to the res. Neither, however, has a proprietary interest in the property nor a proprietor's right to its possession. Like the typical trustee under a corporate bond indenture, the building authority, although the primary recipient of payments from the ultimate user, acts only as a conduit of funds between the user and the bondholders. ${ }^{32}$

Both the trust deed and the building authority device contain a defeasance which, in the former, is usually explicit. In many building authority instruments the defeasance is likewise explicit, and provides that title to the project will pass to the occupying government when the authority's bonds are retired. ${ }^{33}$

purposes as spelled out in the commission's charter. Modern building authority documents rarely contain words of trust. However, this terminology should not be considered essential to the Rcynolds court's theory. Presumably all corporate bodies take property merely to further the execution of their corporate purposes.

32. The authority may even abdicate its function as a conduit if the lender and the using agency so agree. For example, in connection with construction of an indoor athletic practice building for the University of Wisconsin, the authority assigned its rentals to the lending banks, and the Regents of the University agreed to pay rent directly to the banks. State ex rel. Thomson v. Giessel, 271 Wis. 15, 72 N.W.2d 577 (1955).

33. The defeasance may be found in one of several documents: the enabling act, the articles of incorporation, the lease from the authority to the government or in some other agreement between authority and government.

The Maine School Building Authority and the Texas National Guard Armory Board are required by statute to convey projects to their lessees upon retirement of the debt incurred in acquiring those projects. Mir. Rev. Stat. AnN. ch. 41, \& 254 (Supp. 1957); Tex. Rev. Civ. Stat. Ann. art. 5890b, $\$ 3$ (1949). Although the Georgia State Bridge Building Authority Act does not require that title to the project be transferred, all the benefits and burdens of ownership do pass to the state.

When each and all of the bonds ... for the payment of which the revenues of any given project or projects have been pledged, . . . have been paid in full, or a sufficient amount for the payment of all such bonds . . . shall have been set aside in trust for the benefit of such bondholders ... such project or projects shall thenceforth be maintained as a part of the State highway system, free from any and all rental consideration: Provided that the State Highway Department shall maintain and keep in repair such free project or projects.

GA. Cone ANn. § 95-2310 (Supp. 1955).

The Michigan County. Building Authority Act permits the governments which incorporate the authority to provide for conveyance in the articles of incorporation. Mrct. Stat. ANn. \& 5.301(13) (Supp. 1957). Pursuant to this act, $\$ .6$ of the articles of incorporation of the Detroit-Wayne Joint Building Authority specifies that, upon retirement of the bonds, the building will be conveyed to the city and county in accordance with an agreement between them. Walinske v. Detroit-Wayne Joint Bldg. Authority, 325 Mich. $562,572,39$ N.W.2d 73, 76-77 (1949).

Indiana school building authorities must give their lessees an option to buy at any time after six years, the price being sufficient to discharge the authority's obligations. IND. Stat. ANn. $§ 28-3222$ (Supp. 1955). Since the rent amortizes the authority's obligations, 
Even when no such express provision exists, the arrangement itself implies a defeasance. The authority is obligated only to the leasing government and the lenders, and, once the bonds are retired, its obligation runs to the government alone. The authority has no further use for the project. ${ }^{34}$ Its directors can be expected to convey the project to the government, for they are either appointed by the leasing government or are officers of that government serving as directors ex officio. In the unlikely event that they should fail to convey the project, no contractual obligation would prevent the state from dissolving the corporation and thus causing all of its assets to pass to the state. ${ }^{35}$ In sum, the building authority device resembles a deed-of-trust variant of the deed absolute with a separate defeasance-for the political position of the authority's directors and the fact that the rents are sufficient to amortize its debt create a defeasance where none is expressly provided. ${ }^{36}$

the option price will steadily decrease until, upon retirement of all obligations, it will be nil. The Indiana County Building Authorities Act permits options but does not set the option price. Ind. Stat. ANN. 26-2513 (Supp. 1955).

Some authorities build projects upon land owned by the lessee government. The government first grants the authority a leasehold for a term of years at a nominal rent or free of rent. The authority then leases back the project at a rent sufficient to service and amortize its debt. See State ex rel. Thomson v. Giessel, 271 Wis. 15, 72 N.W.2d 577 (1955). If the lease, the lease back, and the bonds are of the same duration, the government's reversion is functionally equivalent to a defeasance. In State $e x r c l$. Thomson v. Giessel, 267 Wis. 331, 65 N.W.2d 529 (1954) (plan held unconstitutional on grounds irrelevant to this footnote), the term of the government's lease to the authority was fifty years or until the indebtedness of the authority be paid and retired, whichever first occurs, thus giving the government a right of entry in the nature of a defeasance.

34. It is significant that the bonds shall mature in thirty years and that the leases shall run thirty years. There is no provision . . . for re-leasing. When a series of buildings will have been leased for thirty years and the principal and interest of the bonds sold to finance their construction will have been paid in full, the authority's responsibility for, and interest in, that particular project, will have been completed. The authority is not in business to make money.

State $e x$ rel. Washington State Bldg. Financing Auhority v. Yelle, 47 Wash. $2 \mathrm{~d} 705$. 713, 289 P.2d 355, 360 (1955).

35. McCutcheon v. State Bldg. Authority, 13 N.J. 46, 59, 97 A.2d 663, 669 (1953).

36. See McCutcheon v. State Bldg. Authority, supra note 35; State c.x rel. Washington State Bldg. Financing Authority v. Yelle, 47 Wash. 2d 705, 289 P.2d 355 (1955). But see Kelley v. Earle, 325 Pa. 337, 190 Atl. 140 (1937) (prior decision that building authority was unconstitutional reversed upon new facts including removal of a lease covenant requiring that the authority convey the project upon retirement of its bonds); State e.r rel. Thomson v. Giessel, 271 Wis. 15, 37, 39, 72 N.W.2d 577, 588, 589 (1955) ("There cannot be a purchase without the passing of title. There is no passing of title in any of these transactions. ... Title to the property does not pass by virtue of the payment of the rentals.").

Though all building authorities imply a defeasance, some operating authorities are not expected to convey projects to traditional units of government when the authorities" debts are paid. In some instances, the authority must continue to hold the project since it is the only organization in the area with bi-state jurisdiction. In contrast, other interstate authorities, such as the federally chartered interstate bridge authorities, see note 8 supra, are expected to convey their bridges to the adjacent states or municipalities. 
In the absence of an express defeasance clause, however, doctrinal technicalities make difficult an implication of conditional terms necessary to render the transaction a mortgage. A deed absolute without a defeasance is construed as a mortgage only upon a finding that the parties intended it to secure the grantor's debt. ${ }^{37}$ And, in a narrow sense, the parties to a building authority transaction did not so intend, since such a debt would be unconstitutional, and the authority structure was designed to circumvent constitutional prohibitions. Of course, in the usual deed-absolute case, the fact that the grantee denies the existence of a debt will not prevent the courts from presuming a debt to be present if the consideration for the deed is disproportionate to the value of the property. ${ }^{38}$ But the application of this reasoning is apparently forestalled by the ingenuity of the authority device, which admits the existence of a debt but states that it is owed by the authority rather than the government.

Nonetheless, even if the parties' intent be accepted in the narrow sense suggested, it need not be determinative. In mortgage law, courts often subordinate the parties' intent to equitable considerations. ${ }^{39}$ If, for example, a borrower does not demand an explicit defeasance, the courts assume that, by virtue of his unequal bargaining power, he was forced into an unconscionable bargain. To protect him, an equity court reconstructs his contract, and, upon finding a mortgage at the bottom of the bargain, ignores the unconditional grant in the documents, though the borrower intentionally may have agreed to this clogging of the equity of redemption.

Although governments usually are not considered weak bargainers, the constitutional debt limit is based upon the premise that, in matters of finance, they are often imprudent. A legislature or municipality, caught between the popular pressures for new developments and against additional taxes, may attempt to escape through excessive borrowing. Not unlike equity's solicitude for the mortgagor, debt limits reflect a determination by the framers and ratifiers of state constitutions that governments are congenital borrowers who often deal unwisely.

Since a government's weakness is not that it agrees to harsh terms of security but rather that it accepts too many loans, building authority cases come before the courts in an unusual posture. ${ }^{40}$ The usual deed-absolute case involves a

37. 1 GlenN, Miortgages $\& 11$ (1943).

38. See 4 Pomeroy, Equity Jurisprudence \& 1196, at 583-85 (5th ed. 1941).

39. The entire history of mortgages illustrates equity's unwillingness to enforce the literal terms of mortgage documents, despite the fact that, at one time, these documents may have reported accurately the intent of the parties. Thus, the mortgagee's title has been reduced from a proprietary interest to a security interest, and evasive devices have been reshaped into equitable mortgages-all in aid of the borrower.

40. The difference in context may significantly affect the attitude of the parties and the judges' response. Unlike most cases, in which plaintiff and defendant are engaged in a dispute of personal consequence, building authority controversies are usually brought to probe judicial reaction to a novel plan. The investment community demands test cases of this sort; a mere bond opinion by reputable counsel does not invariably suffice. Thus, the Allstate Insurance Company conditioned its agreement to purchase an entire issue 
borrower seeking to redeem, although he had previously agreed to accept strict foreclosure at the due date. Thus, to reach an equitable result, a debt must be found from which a mortgage can be deduced. In contrast, the Reynolds court found a mortgage from which it deduced a debt. The same realistic

of authority bonds upon a decision by the state supreme court that "all transactions with reference to the acquisition, construction, and financing of the state-office-building project, including the provisions of this commitment, the statutes underlying such transactions and the security to be given securing the loan to be made to the [Authority] Corporation are valid, subsisting, and enforceable in the hands of Allstate." State c.r rel. Thomson v. Giessel, 267 Wis. 331, 337, 65 N.W.2d 529, 532 (1954).

Since a specific lender cannot make such a demand in a public offering of the authority bonds, the officials involved often attempt to manufacture a cause of action to obtain a judgment which will sweeten the market. The Governor of Maine, in propounding quustions concerning the Maine School Building Authority to the supreme court, prefaced his questions with "Whereas, the Authority is unable to issue its revenue bonds unles: prior thereto said questions of law have been resolved . .." Opinion of the Iustices, 147 Me. 410, 411, 105 A.2d 454-55 (1952). That court refused to render an advisory opinion, but upon other occasions the advisory opinion device has been successfully employed. E.g., Opinion of the Justices, 88 N.H. 484, 190 Atl. 425 (1937). Most states have not established a general advisory opinion procedure. To remedy this, the Oklahoma turnpike authority acts authorize the state supreme court to render declaratory judgments in connection with the authorities. Unless interested individuals appear to protest, the action is conducted in ex parte form. 69 OkLA. STAT. ANN. $\$ 668$ (1950). In the frist such action, many protestants entered. Application of Oklahoma Turnpike Authority, 203 OKla. 335, 221 P.2d 795 (1950). A subsequent test case was ex parte. Applications of Oklahoma Turnpike Authority, 277 P.2d 176 (Okla. 1954).

The quo warranto procedure is also available to test the constitutionality of an authority's enabling act and plan of business. Though quo warranto has been utilized, People $c .2$ rel. Greening v. Green, 382 Ill. 577, 47 N.E.2d 465 (1943), it appears to occur less frequently than cases which arise on patently sham issues. For example, the Washington Supreme Court held a state building authority unconstitutional in an action of mandamus to compel the state auditor to issue a warrant for ten dollars compensation to a stenographer employed by the authority. State ex rel. Washington State Bldg. Financing Authority v. Yelle, 47 Wash. 2d 705, 289 P.2d 355 (1955). The Wisconsin Turnpike Commission was upheld in a dispute over a voucher for a $\$ 155$ typewriter. State $e x \mathrm{rcl}$. Thomson v. Giessel, 265 Wis. 185, 60 N.W.2d 873 (1953). In Ohio, the Secretary of State refused to attest bonds of the Public Institutional Building Authority and thereby enabled the court to rule on the constitutional question in an action of mandamus against him. State ex rel. Public Institutional Bldg. Authority v. Griffith, 135 Ohio St. 604, 22 N.E.2d 200 (1939).

Some cases are taxpayers' suits. Although the reports usually do not indicate the taxpayers' motive for suing, one court suggested that the taxpayer did not resemble the usual adversary party and observed that his contentions of unconstitutionality "are somewhat sketchily supported by argument and citations in the brief, and counsel for plaintiff made no oral argument. Perhaps, as sometimes happens in 'friendly suits,' his function in this case is similar to that of the 'devil's advocate' at the canonization of a saint." Wells v. Housing Authority, 213 N.C. 744, 747, 197 S.E. 693, 695 (1938).

Frequently, courts predisposed to uphold the authority device also willingly extend the scope of their opinions so that their opinion will help promote the sale of the authority's bonds. In Monarch Mining Co. v. State Highway Comm'n, 128 Mont. 65, 270 P.2d 73S (1954), although the court held only that the plaintiff taxpayer lacked standing to sue, since he would not be adversely affected, the court added that the bonds would not violate the state constitutional debt limit. In State ex rel. Thomson v. Giessel, supra, the court 
approach, however, which permits courts to cut through form to substance in the deed-absolute cases, also can justifiably be applied in this area to discover a mortgage debt disguised as a contract for rent.

Even if, by their terms, the doctrines supporting equitable mortgages are not applicable to all building authorities, they are close enough to warrant an extension by analogy. Despite the separate corporate personality given the authority by the legislature, the trust deed furnishes ample precedent for construing a building authority as a mere contractual device. The existence of a separate jural personality, though apparently sufficient to avoid the debt limit in the Kennebec case, need not be conclusive. The Kennebec operating authority's corporate personality had a functional counterpart: a business enterprise with a separate commercial income. Reynolds, on the other hand, involved a building authority which lacked such an enterprise and simply policed the contractual rights of the city, the lenders and the building contractor. Just as the law of mortgages, in construing the relationship of the parties to a transaction, reduces a live trustee to a contrivance, so also should the law recognize a corporate building authority-admittedly a creation of the law, without a functional counterpart-as a similar artifice.

The Reynolds case is unique in its reasoning. Many later decisions have also held building authorities unconstitutional, but none has used the mortgagedeed-of-trust analogy. Even the Supreme Judicial Court of Maine, while recently citing Reynolds with approval, sought another ground for declaring a proposed state building authority unconstitutional and based its opinion upon the identity of rent payments with the cost of financing the project. From this identity, it reasoned that the plan was an installment purchase-a device long recognized as unconstitutional. ${ }^{41}$ Other courts have argued that, if a scheme merely channels government funds to the payment of bonds, the bonds are government debts; 42 and that the interposition of an authority's corporate

faced the question whether a commission formed to study the feasibility of a turnpike could buy a typewriter. Statutes provided that with the Governor's concurrence, this planning commission could proceed to form an authority to build a turnpike, if it found the turnpike feasible. While ruling that the planning commission could buy a typewriter, the court added that, if the commission did find a turnpike feasible and if an authority were subsequently formed, the bonds of the authority, its power of eminent domain, its tax exemptions and its power to establish roadside concessions would be constitutional. In Walinske v. Detroit-Wayne Joint Bldg. Authority, 325 Mich. 562, 39 N.W.2d 73 (1949), although the supreme court upheld the court below in deciding that the authority device was constitutional, the superior court disagreed with the procedure of summary dismissal and ordered that a decree be entered. A summary dismissal, needless to say, would not be influential in financial circles as would a decree supported by an opinion which held the authority constitutional.

41. Opinion of the Justices, 146 Me. 183, 79 A.2d 753 (1951); accord, McCutcheon v. State Bldg. Authority, 13 N.J. 46, 97 A.2d 663 (1953) ; State ex rel. Washington State Bldg. Financing Authority v. Yelle, 47 Wash. 2d 705, 289 P.2d 355 (1955).

42. State v. Volusia County School Bldg. Authority, 60 So. 2d 761 (Fla. 1952); Hively v. School City of Nappanee, 202 Ind. 28, 169 N.E. 51 (1929); State ex rel. Public Institutional Bldg. Authority v. Griffth, 135 Ohio St. 604, 22 N.E.2d 200 (1939). 
entity does not alter the essential character of the transaction. ${ }^{43}$ Both this and the recent Maine approaches are eminently realistic. Nevertheless, by accepting the corporate form of the authority but finding it merely a part of a credit device, the Reynolds case shows greater insight. Furthermore, by construing the authority as a mortgage trustee, the Reynolds rationale emphasizes the authority's duties to the bondholders, a matter of considerable importance.

\section{Building Authorities As Lessors}

Once courts decide to honor the integrity of the building authority device, they proceed readily to the conclusion that the authority's bonds, being nongovernmental, do not violate constitutional debt limitations. By analogy to special districts, these obligations of the corporate authorities are not, themselves, debts of any traditional unit of government. Authorities' leases, however, are disposed of with less facility, for a lease executed by a lessee-government and an independent lessor-authority would appear to evidence a governmental debt subject to constitutional restriction. Nonetheless, three arguments have been advanced to exempt rent obligations from any limitation. These arguments are bottomed on the special-fund theory, the executory-contract ex-

43. "If the acts proposed to be done in financing the enterprise are valid, then such acts do not require conferring the status of a corporation upon the agency, though it might be of practical convenience and value to do so. ..." State Office Bldg. Comm'n v. Trujillo, 46 N.M. 29, 39, 120 P.2d 434, 440 (1941).

Judge Critz, dissenting in Texas Nat'l Guard Armory Bd. v. McCraw, 132 Tex. 613, 635, 126 S.W.2d 627, 640 (1939), declared:

To my mind this Act, in so far as it authorizes rental or lease contracts with the State, and long-term bonds of the Board based thereon, presents a legal impossibility, and a legal paradox.... Under such a law, while the Board holds the legal title, such title holding is a pure fiction. The real title is in the State from the beginning. Thus we have one agency of the State taking the State's own property and leasing it to the State, for a stipulated rental to be paid by the State, and bonds issued on such rental. I cannot agree that such a scheme is possible. One cannot rent his own property to himself.

Conversely, in State v. Florida State Improvement Comm'n, 160 Fla. 230, 34 So. $2 \mathrm{~d} 443$ (1948), the theory that interposition of a building authority would not change the character of the transaction enabled the court to hold a plan constitutional. Article IX, \$ 16 of the Florida constitution imposes a special gasoline tax, the proceeds of which must be used for "the construction or reconstruction of State Roads" and the "lease or purchase of bridges." The Florida State Improvement Commission planned to build a highway, use the State Road Department as its prime contractor, and to lease the highway to the State Road Department which then would pay the rents from the constitutional gasoline tax fund. The court first held that the debt limit did not apply to the tax fund obligations. But, it was argued, the constitution did not permit the use of this fund for highway rentals. Only bridges could be leased with this money. In connection with roads, the fund must be used solely for road construction or reconstruction, not rental. The court answered that "it cannot be said that the State Road Department is not lawfully 'constructing' the road within the contemplation of the Constitution. This being the situation, it is our view that the payment of interest on the bond proceeds is merely a legal and necessary incident to that venture." Id. at 245,34 So. 2 d at 451 . 
ception, and the proposition that future rents are not debts as a matter of common law.

\section{The Special-Fund Theory}

The special-fund theory is rarely applicable to building authorities, since the lessee-government usually pays the rents from its general funds. Special assessments or grants-in-aid finance some government activities, however, and, arguably, the special-fund theory validates rent obligations payable from these sources.

Some exceptional cases clearly involve a special fund. For example, the Florida State Improvement Commission financed the Lower Tampa Bay Bridge and then leased the bridge to the state, which charged bridge tolls to meet the rent obligation. ${ }^{44}$ Thus, though sponsored by a formal building authority, the project receives commercial income which creates a special fund to amortize the debt. Although the state could have financed the bridge by its own issue of revenue bonds, the interposition of an authority does not make the special-fund theory inapplicable.

In other cases, involving authorities created to construct new office buildings for state agencies, the existence of a special fund is not so obvious. The fund theory is put forward, however, when the buildings are rented to financially autonomous agencies, such as those which administer unemployment compensation and are supported by federal grants, ${ }^{45}$ or those which handle workmen's compensation and defray their costs through special assessments on compensation insurers. ${ }^{40}$ Two cases have used the special-fund rationale to permit building authorities to receive rents from such agencies. ${ }^{47}$ Though on a purely verbal level the special-fund theory may be applicable to this practice, this use of the theory does not appear legitimate. The lessee-agencies are part of the machinery of government and are financially independent by historical accident alone. Unlike a sewerage system, a toll bridge or an airport, they receive no commercial income from their customers. Rather they reallocate wealth in implementing a social policy to which government is committed. Admittedly, however, the distinction between commercial and noncommercial government income is not always self-evident, witness the difficulty the courts have had with the distinction between proprietary and governmental activities in construing the extent of municipal immunity from suit.

The two foregoing cases present further complications, for in each instance

44. State v. Florida State Improvement Comm'n, 52 So. 2d (Fla. 1951).

45. 49 Stat. 626 (1935), as amended, 42 U.S.C. $\$ 502$ (1952).

46. Dodd, Adaministration of Workmen's Compensation 807 (1936).

47. MicArthur v. Smallwood, 225 Ark. 328, 281 S.W.2d 428 (1955); State v. Florida State Inprovement Comm'n, 158 Fla. 743, 30 So. 2d 97 (1947). The West Virginia State Office Building Commission adopted the same plan and leased its building to the State Department of Employment, the Merit Council and the Workmen's Compensation Fund. Council of State Governaments, Public Authorities in the States 99 (1953). Apparently the West Virginia program has not been tested in the courts. 
the building has several tenants. The Florida Industrial (workmen's compensation) Commission, for instance, rents an entire building from an authority, but sublets portions of it to other state agencies. Although the state's general funds support the other agencies, the court held this leasing arrangement unrestricted by the constitutional debt limit. Actually, receipt of payments from the sublessees by the Industrial Commission's treasury should cause the treasury to lose its special-fund status, since the state would be feeding the fund with tax receipts. But the court skirted this point.48 Similarly, the Arkansas court approved a plan for a building to be occupied by the workmen's compensation commission, the public service commission, the attorney general, and the supreme court, its clerk and library. ${ }^{49}$ The workmen's compensation commission was to pay the rent for its space from its own treasury, which was characterized as a special fund. Although the public service commission had to meet its administrative expenses with state-appropriated revenues, these funds were replaced in the state treasury by periodic assessments upon all public carriers and utilities within the commission's jurisdiction. The court held these funds to be a conceptually discrete portion of the general state revenues, and held that portion to be the source of the commission's appropriations. $^{50}$ Likewise, the rents for the court and the attorney general's office

48. "Appellant tacitly admits that ... [three cases] conclude the point of whether or not sums received in consideration for sub rental for office space not used by the Florida Industrial Commission . . . may be used to service the revenue certificates brought in question, since no assault is made on the use of the funds derived from these sources." State v. Florida State Improvement Comm'n, 158 Fla. 743, 746, 30 So. 2d 97, 98 (1947). The three cases do not conclude the issue, however, for none involves a fund-feeding plan. See State ex rel. Watson v. Caldwell, 156 Fla. 618, 23 So. $2 d 855$ (1945) (State Improvement Commission Act held constitutional; no specific plan and hence no specific source of income considered) ; Hopkins v. Baldwin, 123 Fla. 649, 167 So. 677 (1936) (bonds payable from student and faculty fees and payments upheld on a special-fund theory); Brash v. State Tuberculosis Bd., $124 \mathrm{Fla} .652$, 169 So. 218 (1936) (bonds payable from revenues of sanatorium upheld on special-fund theory). Compare Brash v. State Tuberculosis Bd., 124 Fla. 167, 167 So. 827 (1936) (previous plan, which included a pledge of the board's state-appropriated funds, held unauthorized by statute, the court expressing doubt that any such plan could be constitutionally authorized).

49. McArthur v. Smallwood, 225 Ark. 328, 281 S.W.2d 428 (1955). Because the project was to be occupied by the supreme court, the entire court disqualified itself. The case was decided by a special supreme court appointed for the purpose.

50. Compare State ex rel. Public Institutional Bldg. Authority v. Giffith, 135 Ohio St. 604, 22 N.E.2d 200 (1939), which held the Public Institutional Building Authority unconstitutional. The court rejected the claim that the special-fund theory applied inasmuch as rental payments for the hospital facilities the Authority planned to build could be covered by fees the state received from pay-patients and contributions from counties which sent indigent patients. "All such funds are first paid into the state treasury and together with the necessary general revenues are appropriated for the use of the department [of welfare] by the General Assembly. ... The revenues ... are not segregated into a special fund but are treated as, and in fact become, revenues of the state ..." Id. at 615,22 N.E.2d at 205 .

A subsequent plan required that the payments were not to be commingled with general state funds. In State ex rel. Public Institutional Bldg. Authority v. Neffner, 137 Ohio St. 
were deemed to be paid from the proceeds of additional costs charged litigants before all courts in the state. In upholding this final aspect of the plan, the court attenuated the special-fund theory beyond its breaking point since these additional litigation costs are not exacted in any given year in which the legislature appropriates rent for judicial and public-attorney office space. Furthermore, the close institutional identification of the court system with the government precludes treating the revenue from additional litigation costs as a special fund. Certainly, courts are not commercial undertakings. In fact, they levy the additional costs only if the legislature fails to pay their rent. Court-imposed costs therefore form not a continuing fund for payment, but a makeshift substitute when payment is not forthcoming from the state treasury. Since the legislature has appropriated rent for the first year, there is no guarantee that these additional court costs are politically acceptable. If they are not, then the threat that they must be levied will coerce the legislature to make future appropriations. Rather than a means for payment, these costs may become sanctions in aid of payment from the state treasury. ${ }^{51}$

\section{The Executory-Contract and Common-Law Theories}

In contrast with the special-fund theory, which is inapplicable to building authority rents absent facts peculiar to extraordinary situations, the two other theories employed to exempt building authority leases from the debt limit are not conditioned upon unusual considerations. If applicable to any building authority, they are applicable to all. In Wisconsin, for example, rents are not debts as a matter of common law. ${ }^{52}$ Adopting a different theory, Pennsylvania

390,30 N.E.2d 705 (1940), the court decreed that this innovation would not cure the defect because the funds which previously had defrayed medical expenses would no longer be available for that purpose and the state would be obliged to replace the diverted funds with tax receipts. The legislature might have predicted this result; the court in Grifith, by its citations, implicitly had adopted the revenue qualification of the restricted special-fund theory.

51. There are other instances of government payments to authorities in lieu of user charges. The city of Norfolk, Va., pays the Elizabeth River Tunnel Commission approximately $\$ 400,000$ a year in consideration for toll-free operation of a bridge. CouncrL of State Governarenrs, op. cit. supra note 47, app. A, at 8 . The state of Alabama was permitted to pay an annual sum to the Alabama State Bridge Corporation, which had defaulted upon its bonds when its commercial income proved inadequate. Scott v. Alabama State Bridge Corp., 233 Ala. 12, 169 So. 273 (1936). Both these schemes exist on a year-to-year basis and thus involve no future contractual obligation by the paying government. Although both schemes illustrate that political pressure may coerce payment from state treasuries in order to discharge special-fund obligations and thereby relieve the burden of user charges, most special-fund obligations are distinguishable from the Arkansas Justice Building Plan. The fact that the Virginia and Alabama legislatures permitted the charges to be levied in the first place evidences their political acceptability. In contrast, the Arkansas legislature sidestepped the problem of political palatability by appropriating funds in lieu of charges for the first year.

52. State ex rel. Thomson v. Giessel, 267 Wis. 331, 65 N.W.2d 529 (1954). An argument to this effect is presented in greater detail by the dissent in McCutcheon v. State Bldg. Authority, 13 N.J. 46, 69-70, 97 A.2d 663, 675 (1953). 
and Indiana have permitted building authority leases under the multi-year executory-contract exception to the debt limit, ${ }^{53}$ and Alabama has a one-year executory-contract exception to debt limits..$^{54}$

Both the common-law and executory-contract theories assume that the contractual relationship between the authority and its lessee government can be terminated with ease. The following paragraphs will attempt to demonstrate that these theories do not justify the building authority device because leases actually cannot be severed except under circumstances which would coerce a government to pay overdue rent, and because, in practice, governments cannot afford the disruption of function or the economic loss which would attend termination.

The One-Year Executory-Contract Exception. In Alabama, where the multiyear executory-contract exception has not been adopted, a building authority lease was struck down as an unconstitutional debt. The court helpfully observed:

"We are ... dealing ... with an unconditional obligation to pay money whether it is available that [future] year or not. If the amount of the stipulated monthly rental were to be payable only out of the current revenues to be received for the fiscal year in which it is payable, a different principle would apply."55 The legislature took the hint and, the following year, enacted a plan whereby the authority would lease its project on an annual basis, the rents under each successive one-year lease to be paid from the lessee's current budget as a current expense. The court subsequently approved this codification of its own dictum, ${ }^{56}$ apparently on the assumption that a failure to renew the lease would relieve the government of its rent obligation.

53. Greenhalgh v. Woolworth, 361 Pa. 543, 64 A.2d 659 (1949); Jefferson School Twp. v. Jefferson Twp. School Bldg. Co., 212 Ind. 542, 10 N.E.2d 608 (1937) ; Protsman v. Jefferson-Craig Consol. School Corp., 231 Ind. 527, 109 N.E.2d 889 (1953). The last two cases effectively overrule Hively v. School City of Nappanee, 202 Ind. 28, 169 N.E. 51 (1929), see note 42 supra, though they purport to distinguish it.

Before the Greenhalgh case, Pennsylvania apparently had upheld building authoritie: under a tortured extension of the special-fund theory. Kelley v. Earle, $325 \mathrm{~Pa} .337,190$ Atl. 140 (1937). In Greenhalgh, the court characterized the special-fund language in Kelley as dictum since the project was not revenue-producing.

54. In re Opinion of the Justices, 252 Ala. 465, 41 So. 2d 761 (1949).

55. Opinion of the Justices, 251 Ala. $91,95,36$ So. 2 d 475,478 (1948).

56. In re Opinion of the Justices, 252 Ala. 465, 41 So. $2 \mathrm{~d} 761$ (1949). Some long term leases incorporate a similar device. For instance, the enabling act for the Illinois State Armory Board provides: "Such leases to the State shall be subject to appropriations to be made by the General Assembly, for the payment of rent under such leases." It further empowers the Board, "in the event of non-payment of rents reserved in such leases to execute leases [of such projects] . . . to others for any suitable purpose." ILL. REv. STAT. ch. 129, § 226(g) (Supp. 1957). This act was held constitutional since the state will not be liable for nonpayment of rent if the legislature fails to appropriate sufficient funds. Loomis v. Keehn, 400 I11. 337, 80 N.E.2d 368 (1948). See also WIs. Stat. $\$ 14.89$ (c) (1955), upheld in State ex rel. Thomson v. Giessel, 271 Wis. 15, 72 N.W.2d 577 (1955); Texas Nat'l Guard Armory Bd. v. McCraw, 132 Tex. 613, 126 S.W.2d 627 (1939). 
The Multiyear Executory-Contract Exception. Although severely criticized, ${ }^{57}$ the rule exempting multiyear executory contracts has nevertheless received considerable support. The United States Supreme Court invoked the rule in a leading decision concerning a lease between a city and a privately owned water company. The Court reasoned that an executory breach by the lessor would excuse the city's performance. ${ }^{\text {ss }}$ Other cases have based the rule on the common practice of businessmen who, in calculating their solvency, exclude their obligations upon executory contracts. ${ }^{59}$ These cases overlook the fact that businessmen also omit from their calculations the future benefits expected to accrue under such contracts-since the benefits would, presumably, be balanced by the contractual liabilities. In any event, calculations of solvency are irrelevant to the debt-limit issue. Borrowing usually has no immediate effect upon solvency, because the money borrowed equals the debt incurred. More important, balance-sheet accounting attempts to estimate an instantaneous business position and, in so doing, assumes that all business can stop, that executory contracts can be broken, and that, upon breach, the parties can obtain satisfactory redress in the market place. ${ }^{60}$ As will presently appear, this assumption is misleading in the context of a government authority lease.

57. 1 Jones, Bonds and Bond Securities $\$ 105$ (4th ed. 1935).

58. There is a distinction between a debt and a contract for a future indebtedness to be incurred, provided the contracting party perform the agreement out of which the debt may arise. There is also a distinction between the latter case and one where an absolute debt is created at once, as by the issue of railway bonds, or for the erection of a public improvement, though such debt be payable in the future by instalments. In the one case the indebtedness is not created until the consideration has been furnished; in the other the debt is created at once, the time of payment being unly postponed.

In the case under consideration [a contract under which a water company would supply the city water for twenty-five years, and the city pay $\$ 1,500$ annually in return] the annual rental did not become an indebtedness within the meaning of the charter until the water appropriate to that year had been furnished. If the company had failed to furnish it, the rental would not have been payable at all, and while the original contract provided for the creation of an indebtedness, it was only upon condition that the company performed its own obligation. Wood v. Partridge, 11 Mass. 487, 493.

Walla Walla City v. Walla Walla Water Co., 172 U.S. 1, 20 (1898).

The Court then added a more cogent reason for the rule: that the opposing view would effectively prevent the city from obtaining a water supply; it could neither borrow to build its own system nor obtain a supply from a commercial company on a short term contract. This argument, however, suggests the advisability of abolishing debt limits rather than rescuing multiyear contracts from their ban.

59. See, c.g., City of Valparaiso v. Gardner, 97 Ind. 1 (18s4).

60. In the event of a breach, the innocent party can only demand the difference between the market price and the contract price. Thus, in a static market his recovery would be nil. This accounting practice, therefore, assumes a static market. That markets are not static reveals the unreality of the accounting premise. This fallacy, however, pervades balance sheet reckoning. For example, assets are usually carried at historical cost less depreciation rather than at replacement value. 
The Common-Law Rule. The Wisconsin view-that future rents are not debts as a matter of common law-derives from ancient precedents: the rule is pronounced as a mystery of the common law inherited unchanged from Coke's Littleton. ${ }^{61}$ However venerable its origins, the rule appears questionable, for future rent has all the attributes of an inmature debt that will become actionable when due. In fact, the rule was possibly poor law even in Lord Coke's day. ${ }^{62}$ At any rate, it certainly seems contrary to modern understanding.

The premise underlying the rule is that future rent will not become due if a lease is terminated prematurely. Littleton contrasted the effect of a "release of all actions" upon a bond with its effect upon a lease. If a creditor holding an immature bond gives such a release, it will bar action upon the bond when due, but if a lessor executes a release, it will not bar his subsequent action for rent. In Coke's words, at the time of the release, the bond was "debitum in praesenti, quanvis sit solvendum in futuro." Rent, however, was "neither debitum nor solvendum at the time of the release made; for if the land be evicted from the lessee before the rent become due, the rent is avoyded; for it is to be paid out of the profits of the land, and it is a thing not meerely in action, because it may be granted over. But the lessor before the day may acquite or release the rent." 63 Future rent, then, could be released, but a "release of all actions" was formally the improper procedure.

61. 2 COKE, LITrLEToN $\$ \$ 512,513$ (15th ed. 1794). "[T] he law as to leases is not a matter of logic in vacuo; it is a matter of history that has not forgotten Lord Coke." Holmes, J., in Gardiner v. William S. Butler \& Co., 245 U.S. 603, 605 (1918) (holding that a landlord's claims for loss of the benefit of his bargain when his tenant went into equity receivership were not provable under the Massachusetts law of leaseholds).

See also 1 Tiffany, Landiord and Tenant $\$ 166$ (1912), which relies upon Coke and early Massachusetts cases, particularly Bordman v. Osborn, 40 Mass. 295 (1839). The Bordman case held that a stockholder who, by statute, was liable for the debts of the company, was not liable for unpaid rent which became due after the stockholder had transferred his stock to another, even though the lease had been executed before the stock transfer.

This rule plagued bankruptcy administration until amendments of the bankruptcy act solved the problem in the 1930's. 3 Collier, Bankruptcy $\{63.32$ (14th ed. 1941). While the bankruptcy courts generally refused proof of landlords' claims for future rents because, as Lord Coke had said, they were not debts, the rule probably had vitality because landlords' claims were secured by the right of entry for nonpayment of rent, whereby the land leased could be recovered. A claim for future rents too closely resernbled a secured creditor's claim for future interest. Since bankruptcy administration is primarily for the benefit of unsecured creditors, omission of landlords' claims seemed consistent with the purpose of the act.

For a history of the doctrine and an argument that it should not apply in present commercial practices, see Radin, Clains for Unaccrued Rent in Bankruptcy, 21 CALIF. L. REv. 561, 22 CaLIF. L. REv. 1, 2-5, 11-13 (1933).

62. Oldden v. Tonto Realty Corp., 143 F.2d 916, 922 (2d Cir. 1944) (dissent of Frank, J.), and authorities there cited.

63. 2 Coke, Litrieton $\$ \$ 512,513$ (15th ed. 1794). 
From Coke's language, early American cases in various contexts developed a rule that rents were not debts. ${ }^{64}$ The decisions reasoned that contingencies might excuse the payment of rent-that the tenant might be ousted by one with title superior to that of his landlord, or that the term could be ended prematurely by surrender or eviction.

Ouster by a superior title holder, whatever its former likelihood, is so improbable in an age of recording acts as hardly to merit consideration. The obligation to pay rent to a building authority is, however, generally contingent upon the lessee's right to continuous possession, and a respectable body of authority exempts contingent obligations from constitutional debt limits. The cases are not in harmony, but one view requires the contingency to be within the control of the obligated government. ${ }^{65}$ Under that test the danger of ouster would not save an otherwise unconstitutional obligation.

Eviction is merely the leasehold variant of the possibility of executory breach of contract, regarded by the Supreme Court as a ground for exempting executory contracts. If a landlord declares an executory breach, the lessee may terminate the lease with impunity. Surrender denominates much the same transaction with the parties reversed; the tenant may terminate the lease if the lessor concurs. Absent this concurrence, however, the tenant may not conclude his obligation to pay rent by surrendering the leasehold.

The Basic Assumption. Thus, the Wisconsin common-law view, and the Alabama (one-year) and Pennsylvania and Indiana (multiyear) rules exempting executory contracts from the debt limit, are essentially similar. All assume that the government's relation with the building authority can be terminated before the authority's debts are fully paid and that no sanctions, the threat of which would coerce the government into continuing the relationship, will be imposed upon its termination. The methods of termination that are envisaged differ. A series of annual leases, as permitted in Alabama, would be terminated by either party's refusal to renew the lease. The multi-year executory-contract exception contemplates the possibility that the authority might evict the lessee-government. And the Wisconsin view presupposes the possibility of surrender as well as eviction. The only important distinction among these views is that, in Alabama, the relationship is formally terminable

64. Wood v. Partridge, 11 Mass. 487, 492 (1814). The early Massachusetts cases do not cite Coke, but they adopt his Latin phrases. The Wood case was the first to use Coke's Latin in connection with rents. Earlier cases, however, applied the same phrases to obligations conditioned upon a successful sea voyage or upon collection of a bill of exchange. Wentworth v. Whittemore, 1 Mass. 471, 472 (1805); Davis v. Ham, 3 Mass. 33, 36 (1807) : Frothingham v. Haley, 3 Mass. 68, 70 (1807). See also the language in Walla Walla City v. Walla Walla Water Co., 172 U.S. 1, 20 (1898), quoted supra note 58 , citing the Wood case.

Bordman v. Osborn, 40 Miass. 295 (1839), supra note 61, relies upon both Coke and the Wood case.

65. Hoyt \& Fordham, Constitutional Restrictions Upon Public Debt in North Carolina, 16 N.C.L. REv. 329, 346 (1938). 
by the government over the authority's objection. ${ }^{66}$ The other theories premise methods of termination which require the authority's assent.

This common assumption-that building authority leases are terminableis unsound. Not only are the parties bound to each other functionally, but the lessee-government's financial interest in the leased project, an interest which increases as its rent payments are used to amortize the debt, is hostage to its continued participation in the plan until the entire debt is retired. Moreover, in order to perform its own functions, the government must continue to lease the authority-built facilities. Substitute projects of specialized design, like schools and courthouses, are, obviously, often unavailable, ${ }^{67}$ and special requirements of physical location constrict the supply of others of more common structure. For example, an office building at the commercial center of a city is not equivalent to an authority's project on the statehouse grounds. Besides, moving to an alternative location often costs prohibitively more than continued occupancy of the authority's project, since by its exemption from property and income taxes and the low interest on its tax-exempt bonds, an authority is enabled to undersell commercial lessors despite the fact that its rents include amortization costs. ${ }^{88}$ Thus, lacking readily accessible and equivalent substitute facilities, the government can abandon a building authority project only by curtailing its functions-usually a legal or political impossibility.

Furthermore, building authorities are likewise unable to terminate a lease arrangement. Since they have no use for profits, the rental payments under the lease meet all their needs. Furthermore, the specialized design and location of many projects precludes their profitable commercial usage. Even if occupancy by a commercial lessee were feasible, it might jeopardize the tax-exempt status of the authority's bonds and thus threaten a reduction of the bondholders' net

66. The Inlinois State Armory Board device which permits the state to terminate the lease with impunity should the legislature fail to appropriate the rent, note 56 supra, similarly permits the state unilaterally to terminate the relationship.

67. Magnusson, Lease-Financing by Municipal Corporations as a Way Around Debt Limitations, 25 Geo. WASH. I. REv. 377, 391-92 (1957). The author indicates that leases of office space, maintenance yards, garages, armories and auditoriums may be terminable.

68. The cost of occupancy must include the expense of operation, maintenance and insurance plus financial costs (interest, profit, and debt amortization). Should the government abandon an authority's project and rent substitute facilities from a private company, there probably would be little change in the operation, maintenance and insurance expenses the rent would have to cover. However, the private company probably would be subject to property taxes and would charge more than a $6 \%$ return on its investment. Of course, an authority's costs, including amortization of the debt, vary with the maturity of the bonds and the interest rate. At $2 \%$ for twenty years, the annual cost of interest and amortization is $6.116 \%$ of the original debt. At $4 \mathrm{x} / 2 \%$ for thirty years, the annual cost is $6.139 \%$. At $5 \%$ for thirty-seven years, the annual cost is $5.984 \%$. Counclu of State Governments, Public Authorities in the States 74 (1953). See note 84 infra. As these figures demonstrate, the tax-exempt feature of authority bonds permits long term borrowing at low rates; private capital generally cannot compete with authority capital. Nonetheless, during a depression, owners of vacant buildings who have abandoned hope for profits, could lease at competitive rates in an effort to minimize their losses. 
income. ${ }^{10}$ Moreover, by and large private tenants are poorer credit risks than government units. Accordingly, unless the government in question could not pay its rent, bondholders might obtain an injunction against an attempt by the authority to seek private tenants in lieu of a satisfactory public one. So long as the government fulfills its obligations under the lease, the authority's 'duty to the bondholders dictates that the lease be continued. For similar reasons, the authority cannot accept surrender, and it must seek renewal of an annual lease.

Should the government default, however, duties to the bondholders would no longer prevent the authority from interfering with the government's possession. Bondholders have no interest in leaving a nonpaying tenant undisturbed. Their interests require the authority to invoke sanctions that will coerce payment from any tenant in default. The authority's right of entry for nonpayment of rent is just such a sanction.

Not only would the authority's entry interrupt essential government activities, it would be financially coercive. Part of every rental payment advances the retirement of the authority's bonds. After all the bonds have been retired in twenty to fifty years, the government is entitled to occupy the facility rentfree and thereafter pay only the cost of operation and maintenance-a substantial expectancy. ${ }^{70}$ If the rent is not paid, the bonds will not be retired on schedule and enjoyment of the expectancy will thus be postponed. To stop the rent while interest continues to accrue on the unretired principle is to deplete sinking funds, if any, or to increase the outstanding obligation, possibly to an amount in excess of the original bond issue. Even worse, if a government wholly abandons the authority's project (by refusing to renew the lease under the Alabama plan or by obtaining authority consent to termination or surrender under one of the other theories), that portion of previous rentals which was allocated to debt retirement would be sacrificed in its entirety. The government's expectancy has no value, of course, if the authority permits the government to continue in possession though in default. The future right to rent-free possession is not worth purchasing if the authority tolerates gratuitous occupancy. To give value to this expectancy, then, the authority must oust any nonpaying tenant, thus coercing payment or effectively compelling the sur-

69. Interestingly enough, income from municpal revenue bonds issued to finance an industrial plant built and operated by the municipality to attract industry is exempt from the federal income tax, even though the muncipality's obligation to pay is limited to the revenue derived from leases to private industrial tenants. Rev. Rul. 54-106, 1954-1 Cum. BuLL. 28. However, where municipal repudiation of an authority's project deprived it of all color of "public purpose," the bonds might lose their tax-exempt status.

70. If the Reynolds mortgage analogy is considered inapplicable, this expectancy cannot properly be called an equity in the property. And if no provision requires title to pass to the lessee government, the courts can honor the fiction that the lease does not constitute a purchase contract and that the government does not have a vendee's equity. Nonetheless, the financial fact remains; the cost of occupancy will not exceed the cost of operation, maintenance and insurance when the debt is completely retired whether title passes to the occupying government or remains in the name of the authority. 
render of the expectancy purchased with prior rentals. Should the authority fail to enter, the bondholders may be able to oust the government by foreclosing their mortgage, or in the absence of a mortgage, they may be able to have the authority superseded by a receiver or a trustee under the bond indenture. In turn, this official can be directed to proceed to protect the bondholders' interests by entry or otherwise. Lacking these remedies, the bondholders may be able to obtain an injunction or writ of mandamus ordering the authority to enter. ${ }^{71}$

In short, the authority's duties to the bondholders and their own remedies in aid of those duties convert authority leases into governmental debts within the meaning of the state constitutions, just as a pledge of government assets converts an otherwise unenforceable claim into a debt. If a municipality purchases the equity in mortgaged property but does not assume the mortgage, it nevertheless is held indebted in the constitutional sense. ${ }^{72}$ Though not liable on the secured debt, it must either redeem the property or suffer the loss of payments previously made. These payments, then, become a pledge securing the government's continued performance of the mortgagee's duties. Similarly, that fraction of the rent which is paid to an authority and then is apportioned to debt amortization serves as a pledge securing the lessee-government's continued performance.

The Wisconsin courts recognize this functional nature of bondholders' remedies in one type of case. Although building authorities have generally been approved in Wisconsin, those constructing projects on government land have encountered constitutional obstacles. One school district planned a rent-free lease of land to an authority which would build a school, and, in turn, lease back the school to the district at a rent sufficient to service the bonds. The court held that the mortgage securing these bonds was unconstitutional, since, by permitting the authority to mortgage its leasehold, the school district had pledged existing government property for the payment of rent. ${ }^{73}$ Although a new plan eliminating the mortgage was then conceived, the court enlarged its

71. Building authority bonds are patterned after revenue bonds. Accordingly, the same general kinds of sanctions are available to building authority bondholders as are employed by holders of revenue bonds. Concerning revenue bondholders' remedies, see Fordham, Revenute Bond Sanctions, 42 CoLum. L. REv. 395 (1942).

72. 15 McQullin, Munictpal Corporatrons 371 (3d ed. 1950); 1 Dillon, MuniciPal Corporatrons $\$ 199$ (5th ed. 1911). But see Burnham v. City of Milwaukee, 98 Wis. 128, 73 N.W. 1018 (1897) (although city entered contracts to purchase park lands, paid part of price and was given possession of the lands, the vendors agreeing to convey title upon payment of balance, the city was not indebted, in the constitutional sense, absent an agreement to pay the remainder despite the fact that the contracts gave the vendors a lien upon the property which could be foreclosed upon city's default); Connor v. City of Marshfield, 128 Wis. 280,107 N.W. 639 (1906) (city purchased waterworks from a private corporation, subject to a mortgage securing bonds of the private corporation, but the outstanding bonds were not regarded as debts of the city).

73. State $e x$ rel. Rogers v. Milligan, 267 Wis. 549,66 N.W.2d 326 (1954). 
earlier position and held that the authority's right of entry for nonpayment of rent converted the leasehold into an unconstitutional pledge. ${ }^{74}$

In another instance, the state planned to use the authority device to finance a new wing for an existing office building. The original scheme was held unconstitutional because the state proposed to lease the entire building to the authority free of rent, and the authority's bonds were to be secured by a mortgage of its leasehold. ${ }^{75}$ Consequently, by a second legislative plan, the state was directed to sell the authority the existing building together with the adjacent land for $\$ 125,000$. The authority's bonds, which financed not only the cost of the new wing but also the price of the fee, were then to be secured by a mortgage. Since, upon foreclosure the state would not suffer forfeiture, as it no longer owned any part of the project, this arrangement was adjudged constitutional. ${ }^{70}$

As precedent for its view, the Wisconsin court cited its own revenue bond case ${ }^{77}$ which adopted the restricted special-fund theory. Since Wisconsin has not attempted to justify building authorities under the special-fund theory, this restriction is doctrinally inapposite. However, the rationale of the restricted special-fund theory might be equally applicable to building authorities. The theory permits purchase-money mortgages of revenue-producing projects and only forbids mortgages upon existing projects presently unencumbered. The threat of foreclosure might be equally coercive in either case. The distinction, however, can be rationalized on the ground that, in each, a different community is coerced. According to the special-fund theory, revenue bonds are not debts of the issuing government, which merely acts as an agent for collection from the community of users. Since the equity subject to a purchase-money mortgage is built by user charges, the threat of foreclosure may coerce the community of users who paid for it, but not the community of electors. Foreclosure of a mortgage upon previously unencumbered government property, however, would coerce the government, in that the community of electors would be impelled to redeem its former asset. ${ }^{78}$ It is not the purpose of this article to

74. State ex rel. Rogers v. Milligan, 269 Wis. 565,69 N.W.2d 485 (1955).

75. State ext rel. Thomson v. Giessel, 267 Wis. 331, 65 N.W.2d 529 (1954).

76. State $e x$ rel. Thomson v. Giessel, 271 Wis. 15,72 N.W.2d 577 (1955).

77. State ex rel. Morgan v. City of Portage, 174 Wis. 588, 184 N.W. 376 (1921).

78. Although no judicial pronouncement expressly adopts this rationalization, it seems implicit in City of Joliet v. Alexander, 194 IIl. 457, 62 N.E. 861 (1902), the leading case on the restricted special-fund theory. The Joliet court held unconstitutional a plan to finance improvements of a municipal water system with revenue bonds payable from the income of the entire system and secured by a mortgage upon the old system and the improvements. The court reasoned that the plan would be constitutional if analogous to financing local improvements with warrants payable only from a special assessment against benefited property. The analogy proved incomplete.

A special assessment is a lien upon individual property and not upon property of the city, but in this case the holders of certificates would have a right to take and appropriate a pre-existing income of the city for the payment of the certificates and also to enforce payment by a sale of property of the city. The certificates would 
investigate the validity of revenue bond financing. In fact, these two communities often are substantially the same. In revenue bond cases, there is at least a colorable argument that the two communities differ. For example, turnpikes are used by cars from other states, and foreign corporations have local stores and plants which use water and sewage facilities. On the other hand, in most building authority cases, the two communities coincide. The government that contributes the initial capital, such as land, is the same government that pays the expectancy-creating rent. If, therefore, a building authority's right of entry compels payment in cases in which the government has contributed initial capital assets to the project, it is also coercive when the government has previously increased the project's net worth by paying the costs of debt amortization.

It follows, then, that, in the absence of facts making the special-fund theory applicable, the building authority device creates a debt in the constitutional sense. The authority and the leasing government are functionally so integrated that to construe the authority as an independent body is to mistake form for substance. Not only does the government require the project for its functions, but that part of the rent which amortizes the debt also becomes a pledge securing the government's future performance. To protect this pledge and continue its functions, the government must seek renewal of the annual leases executed under the Alabama plan, and cannot terminate the long-term contracts permitted in other states. To fulfill its obligations to its bondholders, the authority is similarly inhibited, unless the lessee-government is behind in its rent. In

be in no sense chargeable upon the property of individuals, but solely upon the income and property of the city, including property already owned by the city.

Id. at 465,62 N.E. at 864 . Implicit here is a distinction between the community of benefited land owners and the community of electors.

No language in the Wisconsin cases indicates that the distinction between approved purchase-money mortgages and all other mortgages is rationalized in this manner. To the contrary, there is reason to believe that the Wisconsin court has no theory to justify this distinction. Firstly, the Wisconsin courts have expressly held that threat of foreclosure is not so coercive of payment as to require forbidding a city to buy property subject to a lien where the city does not contractually assume the debt secured. Burnham v. City of Milwaukee, 98 Wis. 128, 73 N.W. 1018 (1897) ; Connor v. City of Marshfield, 128 Wis. 280, 107 N.W. 639 (1906). Secondly, the courts have not applied the restricted specialfund theory when the revenue producing facility was constructed upon land purchased especially for the project, even though the land was purchased with general government funds and was encumbered by a mortgage securing the bonds issued to finance the projects. Morris v. Ellis, 221 Wis. 307, 266 N.W. 921 (1936). In view of these precedents, the school building authority cases and the state office building wing cases, notes 73-76 supra, stand only for the proposition that a security transaction may encumber previously owned assets only if, in connection with the plan, the assets have been altered in character.

Under those cases, if the lien encumbers assets which the government contributes in kind, such as land, the plan is unconstitutional. If, on the other hand, the government purchases land especially for the project, as in the Morris case, or purchases an equity in a mortgaged water system, as in the Burnham case, the plan is constitutional because the assets were not previously owned in kind but are the successors to previously owned money. This position is indefensible. 
fact, the authority's power to terminate the lease, rather than indicating that no debt is involved, proves that the rent obligation is actually a debt, since by the exercise of this power the authority can coerce payment. The Reynolds case therefore seems the most perceptive in this area. Its analogy to a deed of trust in the nature of a mortgage is singularly apposite. The trustee's strict duties owed the lenders limit his function and reduce him to a contractual device. The authority's duties to the bondholders similarly color the entire building authority device and convert the "rents" into "debts."70

\section{The Consequences}

No satisfactory theory has been advanced which justifies exempting the building authority device from constitutional debt limits. Of course, peculiar circumstances may bring an authority within the special-fund theory, but such a transaction would not require an authority for its constitutionality. Absent such peculiar facts which in themselves would exempt the debt from the constitutional limit, the building authority device constitutes a flagrant violation of state constitutions. Conceptually, therefore, the integrity of constitutional government dictates that either the building authority device or the provisions restricting government debt be abandoned.

Actually, however, the principle of constitutional supremacy has never been controlling in this area, inasmuch as the entire history of debt limits is one of evasion. The three evasive theories mentioned at the beginning of this article rest upon foundations almost as weak as the building authority device itself. An executory contract, as a matter of fact, is not easily avoided should the government later find it excessively burdensome. Special districts are often merely bureaus of a traditional unit of government, and their corporate form

79. This analysis cannot be applied with equal vigor to all Wisconsin building authorities, however. In order to permit projects on government land, some of those authorities eschew all security. Not only is there no mortgage securing the bonds, but the authority has expressly waived its right of entry for nonpayment of rent. This kind of transaction was held constitutional in State ex rel. Thomson v. Giessel, 271 Wis. 15, 72 N.W.2d 577 (1955).

Clearly, the mere failure to pay rent would not jeopardize the government's right to occupy the project. Thus, the authority could not force the government to sacrifice its expectancy. However, the government would still be liable for each installment of rent as it came due. Though this obligation runs only to the authority-lessor, the bondholders can have the benefit of it in a suit by the indenture trustee, if any, or by a receiver appointed pursuant to a creditor's bill. The obligation, therefore, appears to have all the attributes of a debt, though a default could not accelerate the due dates of future installments.

The absence of all security provisions does not bolster the validity of the Wisconsin common-law rationale that rents are not debts. Though the lack of security provisions makes a default less disastrous to the government-lessee, it does not affect the authority's duty to its creditors. The authority cannot evict or accept surrender from the lessee so long as it is able to pay the rent. Only the tactics of the situation are changed. Upon default, the authority must sue on each installment as it matures and must not jeopardize similar causes of action in the future by interfering with the government's right to possession under the lease. 
should be considered incidental. ${ }^{80}$ Special funds are special largely because the government designates them as such. This accounting procedure may have little functional significance. The sponsoring government, to preserve its good name in financial circles, may have to assume special-fund obligations should the fund prove inadequate. Also, a special fund's creditors, pursuing their remedies, may coerce payment from the general fund, for the foreclosure of a mortgage securing special-fund obligations can be as onerous to the government as the foreclosure of a mortgage securing general obligations. And if foreclosure is unavailable, the holders of defaulted bonds may compel an increase of rates payable to the special fund. ${ }^{81}$ This, in turn, may induce the rate-payers to exercise their political power to force the government into assuming the debt or making periodic additional payments to preserve the existing rates.

The building authority is, then, merely a new device which, in the tradition of its predecessors, flouts the constitution. Like the others, it has had a mixed judicial reception, depending upon the relative values that courts have accorded constitutional principles and the government's obligation to fulfill popular needs. Not unexpectedly, the courts have held building authorities constitutional for reasons other than those given in the cases. Judicial approval of the authorities indicates a recognition of the facts that the capital needs of government must be met, and that debt limits, as they now stand, prohibit a government from fulfilling the functions expected of it.

Though the building authority device is, strictly speaking, repugnant to constitutional government, it is consistent with democratic government. Building authorities have been established by acts of responsible legislatures or pursuant to the enabling acts of those legislatures. Generally, the limitations upon the powers of representative bodies are not strictly honored unless they are considered essential to certain democratic concepts. Substantive due process is in eclipse except in the field of civil rights, education and other areas buttressed by equalitarian considerations and the needs of representative government. The judicial approval of building authorities created by democratic, representative bodies is part of this trend..$^{82}$

This is, perhaps, as it should be. Certainly, public attitudes toward public debt have changed greatly in this century. Though morality still requires a balanced budget or a surplus to reduce outstanding governmental debt, this ethical mandate has become a hope rather than a guiding principle. The electorate might not, today, consider government debt an evil which should be con-

80. If the chief officials of the district are appointed by a traditional unit of government, the district closely resembles a department of the appointing government. Even if the chief officers are elected, the similarity is not destroyed, for lesser administrative offices are not uncommonly elective.

Indeed, some authorities have recognized that a special district may merely be a bureau in corporate clothing. See Annot., 171 A.L.R. 729 (1947).

81. Fordham, Revenue Bond Sanctions, 42 Colum. L. Rev. 395, 419-39 (1942).

82. An additional example may be drawn from the field of corporate law. There, the ultra vires doctrine no longer limits significantly the powers of directors of private corporations. 
stitutionally banned. Imprudent debt, like any other government imprudence, should be avoided, but the electorate might think that this can best be accomplished by electing prudent officials.

Nonetheless, those courts which have approved building authorities have deprived the electorate of an opportunity to express its changed attitude in this field directly. "Debt" is not a pleasant word. It denotes something bad. No one is for it for its own sake. Since an intelligent appraisal of debt is possible only in the face of a choice between either foregoing debt or foregoing its benefits, the courts, by permitting some benefits of debt through building authorities, have deprived the electorate of an opportunity to make an intelligent choice.

This has not been accomplished without cost. The financial community accepts building authority bonds less readily than it does direct government obligations. Accordingly, interest rates range from one half of one per cent to one per cent higher upon building authority bonds than upon full-faith-and-credit government obligations. ${ }^{83}$ The effect of this can be evaluated from the following example. If a government borrows directly at $2 \mathrm{r} / 2$ per cent and retires the debt over a thirty-year period, it annually must budget $\$ 47.78$ for every $\$ 1000$ originally borrowed. But if, by using a building authority, it must accept a $3 \mathrm{r} / 2$ per cent interest rate, that same $\$ 47.78$ per year will carry only $\$ 878.79$ of original debt. Thus, for the same annual cost, the government is forced to borrow 12 per cent less. Put the other way, to obtain the same total loan, the government must pay an additional $\$ 6.59$ per thousand-some 14 per cent, in annual cost. ${ }^{84}$ Therefore, a government which utilizes a building authority to sidestep debt limits must either forego the full benefit of its credit by borrowing less or else increase taxes and the possibility of default as well. In sum, the debt limit, a symbol of financial prudence in the nineteenth century, has ironically spawned a financially imprudent instrumentality in the twentieth.

It might appear, then, that the courts should have held building authorities

83. Ellinwood, Use of Special Authorities to Finance School Improvements, 25 Municipal Finance 48, 52 (1953) ; Councll of State Governarents, Public AuthoriTIEs IN THE States 70-74 (1953); Magnusson, Lease-Financing by Municipal Corporations as a Way Around Debt Limitations, 25 Geo. WASH. L. REv. 377, 395-96 (1957).

84. The following table, extracted from Council of State Governarents, op. cit. supra note 83 , at 74 , gives the annual cost of a $\$ 1,000$ loan over selected periods at various interest rates.

$\begin{array}{lcccc}\text { Rate of Intcrest } & 20 \text { years } & 30 \text { years } & 37 \text { years } & 50 \text { years } \\ 2.0 \% & \$ 61.16 & \$ 44.65 & \$ 38.51 & \$ 31.82 \\ 2.5 & 64.15 & 47.78 & 41.74 & 35.26 \\ 3.0 & 67.22 & 51.02 & 45.11 & 38.87 \\ 3.5 & 70.36 & 54.37 & 48.61 & 42.63 \\ 4.0 & 73.58 & 57.83 & 52.24 & 46.55 \\ 4.5 & 76.87 & 61.39 & 55.98 & 50.60\end{array}$

If the use of an authority inflated the rate from $2 \frac{\mathrm{T}}{2} \%$ to $3 \%$ in the textual example, the annual cost per thousand would increase from $\$ 47.78$ to $\$ 51.02$-nearly $7 \%$. If the borrowing government could not assume this added burden, borrowing power would diminish to $\$ 936.50$, a loss of more than $6 \%$ 
unconstitutional and thereby forced the legislatures to re-evaluate the current consensus on public debt. As a result, debt limits night have been repealed br revised, in order to relieve government of its nineteenth-century straight jacket and permit the exercise of twentieth-century functions.

The experience in Maine and Georgia, however, indicates that such judicial firmness might prove vain. After the Reynolds case had effectively barred building authorities in Maine, there were no further attempts to use the device until 1951. That year, the court held a state office building authority unconstitutional ${ }^{85}$ and restricted the usefulness of the recently established Maine School Building Authority by holding that it could only rent projects to municipalities whose outstanding debt, when added to the cost of the school building, remained within permissible constitutional limits. ${ }^{86}$ Thereafter, the Maine constitution was amended by appending to the section limiting municipal debts the proviso, "Long term rental agreements not exceeding forty years under contracts with the Maine School Building Authority shall not be debts or liabilities within the provisions of this section." 87

Georgia has had a similar history. The Supreme Court of Georgia refused at an early date to extend to multiyear contracts the executory-contract exception to the debt limit. 88 Seeking a way to permit local governments to finance hospitals, the legislature proposed a constitutional amendment authorizing local governments to lease projects from authorities. ${ }^{89}$ This amendment was adopted and, in 1955, enlarged to permit the state and its agencies, as well as counties and municipalities, to rent any project from any authority for a period not exceeding fifty years. ${ }^{90}$ Although the first opinion concerning the amendment held that the debt limit still applied to authority leases-thus necessitating a statute similar to Alabama's ${ }^{21}$-subsequent cases exempted authority leases from the debt limit. ${ }^{22}$

85. Opinion of the Justices, 146 Me. 183, 79 A.2d 753 (1951).

86. Opinion of the Justices, 146 Me. 295, 80 A.2d 869 (1951).

87. ME. Const. art. IX, § 15. The amendment had a stormy history. The debt limit not only inhibited necessary school construction, but other projects as well. Consequently, in 1951 the legislature proposed two amendments, each of which detailed a proposed section 15. The first proposal raised the debt limit from $5 \%$ to $71 / 2 \%$. It was defeated by the electorate. The second amendment, as set forth in text, was adopted by the electorate as Amendment LXXIII and proclaimed by the Governor on September 26, 1951. In 1954 the legislature again proposed an amendment to elevate the debt limit to $71 / 2 \%$. The School Building Authority exception, which had been adopted in the meantime, was omitted. This amendment was adopted by the electorate as Amendment LXXVI and proclaimed by the Governor on September 21, 1954, thus inadvertently repealing the proviso adopted in 1951. Opinion of the Justices, $150 \mathrm{Me}$. 362, $134 \mathrm{~A} .2 \mathrm{~d} 511$ (1955). A third amendment, Amendment LXXX, re-enacting the proviso, was proposed, adopted and promulgated by the Governor on September 26, 1955.

88. City Council v. Dawson Waterworks Co., 106 Ga. 696, 32 S.E. 907 (1899).

89. See DeJarnette v. Hospital Authority, 195 Ga. 189, 23 S.E.2d 716 (1942).

90. GA. Const. art. VII, § VI, para. 1.

91. DeJarnette v. Hospital Authority, 195 Ga. 189, 23 S.E.2d 716 (1942).

92. Sheffield v. State School Bldg. Authority, 208 Ga. 575, 68 S.E.2d 590 (1952); McLucas v. State Bridge Bldg. Authority, 210 Ga. 1, 77 S.E.2d 531 (1953). 
The Maine and Georgia amendments are expensive, patchwork remedies when compared to outright repeal of the debt limit. Authority leases, and hence the bonds behind them, are limited to forty or fifty years. While Georgia permits almost any kind of project to be leased from any authority, ${ }^{93}$ in Maine, only leases from the School Building Authority avoid the debt limit, and probably all Maine projects must be related to education. Also, the School Building Authority has discretion to refuse to finance projects which it feels would overburden the municipality's budget. ${ }^{94}$

These restrictions, if desirable, could have been included more economically in a constitutional amendment which permits direct-obligation borrowing, since government bonds would permit lower interest rates than are possible when an authority is interposed between the bondholders and the ultimate obligor, the government. In other states, where building authorities are judicially tolerated, legislators might accept the higher cost of authority finance as preferable to a public campaign to amend the constitution. Maine and Georgia, however, undertook such campaigns. Why, then, did they retain authorities?

Although legal materials shed little light upon the political history of these amendments, an understanding of the slogans involved may well provide the answer. Public debt, though no longer anathema, is still not accepted unemotionally. "Debt" is a fundamentally immoral word to large segments of the electorate. In contrast, the wording of the Georgia and Maine amendments, permitting leases, does not flag this emotional fear. ${ }^{95}$ Renting, after all, is regarded as the practice of an honorable man who needs the use of a facility

93. Well, nearly any authority. A Georgia plan whereby the state highway department was to rent a project built in Georgia by the Florida Ocean Highway and Port Authority was held unconstitutional in State v. Blasingame, 212 Ga. 222, 91 S.E.2d 341 (1956). Said the court, "It would be difficult to conceive of a deliberate intention upon the part of the people of Georgia to authorize by the Constitution contracts by the State and its subdivisions with agencies ... of a communistic country for the performance by such communistic agencies of governmental functions within the State of Georgia." Id. at 225, 91 S.E.2d at 343. Apparently, in Georgia, foreigners are foreigners and since leases with communistic agencies are taboo, so are those with Florida authorities.

94. The extent to which the Maine School Building Authority Act is incorporated by reference in the constitutional amendment, quoted in text accompanying note 88 supra, is uncertain. Could the legislature amend the act to require the Authority to issue bonds for all school authorities who make demand, regardless of their financial condition? Could the legislature permit the Authority to finance a swimming pool to be used both for education and recreation? A pool to be used only for recreation? A new city hall in Waterville, if it contained office space for the local school officials? These questions may not merely be academic. As the history of the Maine amendments indicates, the public works crisis in Maine is not limited to schools. Note 87 supra. Industrial and commercial progress will probably increase the need for public works and it is not unlikely that the legislature will respond by extending the Maine School Building Authority's sphere of operation without an additional constitutional amendment.

95. Perhaps this factor caused the electorate of Maine, when offered both a constitutional amendment which raised the debt limit and one permitting a building authority, to reject the proposal raising the debt limit and to adopt the amendment permitting the authority. See note 87 supra. 
which he cannot afford to purchase. Practical politicians, then, would rather support the building authority device than a repeal or liberalization of the debt limit. Thus, in circumventing the debt-limit barrier to desirable public projects Americans have adapted their institutions to their moral slogans. In the process, they have paid, and pay, unnecessarily high interest rates-the price of apparent virtue. ${ }^{98}$

96. The history of debt limits is merely a recent chapter in the long history of commercial taboos and their evasion. In the middle ages, borrowing was not thought dishonorable, but charging of interest, no matter how little, was considered usurious and condemned by law and church. One evasive device employed a combination of three contracts. Borrower and lender would form a partnership, the lender supplying the capital. The borrower would then insure the lender against loss. Finally, the lender would sell his share of the uncertain future profits to the borrower for a sum certain. "There was no reason why the three contracts-the partnership agreement, the insurance contract and the sale of a future uncertain profit-each one legal in itself, should be presumed to be illegal when entered into by the same two persons. This so-called triple contract (contractus trimus), which became an established practise in the latter part of the fifteenth century, was in effect an agreement with all the implications of a modern loan transaction." Salin, Usury, 15 Encyclopedia of tHe Social Sciences 193, 196 (1934). Similarly, an authority's happy combination of lease and special district, each considered legal in itself, is often upheld and the concerted effect ignored.

Even the respectable leasehold was originally an evasive device.

In the English feudal economy prior to the thirteenth century . . . leases, rather than being for purposes of husbandry, probably were used most frequently as devises to evade the laws against usury. $A$, being in need of funds, would make a lease for years to $B$ for a lump-sum consideration paid in advance. $B$ would expect to recoup the consideration and a profit from the use of the land during the term. This was the so-called premium lease. The modern mortgage grew out of a somewhat similar use of the lease where a debt was created and the lease served as security.

1 American Law of Property $\$ 3.1$ (Casner ed. 1952).

Thus have commercial needs been accommodated to current law and morality. 